\title{
The Global Social Enterprise Lawmaking Phenomenon: State Initiatives on Purpose, Capital, and Taxation
}

\author{
Carol Liao \\ Elsir U. Tawfik \\ Pat Teichreb*
}

\begin{abstract}
New laws designed to foster and govern social enterprises are propagating throughout the world. Beyond American initiatives, relatively little has been written to date on the global contagion of lawmaking to address the burgeoning field of social enterprise. Increased corporate lobbying to transplant American "benefit" corporation legislation into other countries, with little sensitivity towards existing legal ecosystems in those nations, has generated an urgency to broaden the literature and unearth the wide range of social enterprise law initiatives occurring across the globe. This article identifies over 40 state initiatives across 30 countries to distinguish this international movement. Critical thematic issues are identified from the available data, in hopes of shifting the focus away from private American interests in non-US countries and adding new knowledge to the development of social enterprise law and policies in the years ahead. This article begins by detailing various ways in which states have defined the purpose of social enterprise and social enterprise-type businesses, including how jurisdictions have experimented between state-run certifications and separate corporate legal structures to meet growing demands from particular sectors and stakeholders. We find that most jurisdictions require social enterprises to have a specific social purpose designed to serve the targeted needs of specific sectors, marginalized groups, and/or vulnerable communities. Next, we examine how new state legislation has sought to ease or restrict capital access for these social enterprises. Finally, we provide a detailed overview of various tax initiatives explored by states to promote and foster social enterprises. We suggest that lawmakers proceed with caution in the development of social enterprise laws, particularly when they are in response to private interest groups, and engage in fulsome discussions on the range of available legal methods to foster social enterprise within their jurisdictions.
\end{abstract}

Partout dans le monde sont créées des lois conçues pour promouvoir et régir les entreprises à vocation sociale. Outre des initiatives américaines, on a relativement peu écrit sur la fièvre, mondialement contagieuse, d'édiction de lois dans le domaine en plein essor des entreprises à vocation sociale. En raison d'un lobbyisme d'entreprise accru en faveur d'une transposition à l'étranger de lois américaines régissant les organisations d'intérêt public, transposition peu soucieuse des systèmes juridiques existants dans ces pays, il est urgent d'enrichir la documentation écrite et de mettre au jour le vaste ensemble

Carol Liao is an Assistant Professor and the Director of the Centre for Business Law, Peter A Allard School of Law, and the UBC Sauder Distinguished Scholar of the Peter P Dhillon Centre for Business Ethics, UBC Sauder School of Business, University of British Columbia. Elsir U Tawfik is an articling student at Miller Thomson LLP and a 2019 JD/MBA graduate of the Peter A Allard School of Law and UBC Sauder School of Business. Pat Teichreb is an articling student at Koffman Kalef LLP and a 2019 JD graduate of the Peter A Allard School of Law. The authors would like to thank Pawanpreet Sran, Kyle Fogden, Erika Hughes, Beate Sjåfjell, Christopher Bruner, Jukka Mähönen, Noel Semple, Vanisha Sukdeo, Sukanya Pillay, and the anonymous reviewers of the Windsor Yearbook of Access to Justice. 
d'initiatives législatives mises en œuvre partout dans le monde en matière d'entreprises à vocation sociale. Pour définir la nature de ce mouvement international, cet article présente plus de 40 initiatives d'État mises en œuvre dans 30 pays. À partir des données disponibles, les auteurs cernent les enjeux thématiques capitaux dans l'espoir de détourner l'attention des intérêts américains privés à l'extérieur des États-Unis et d'apporter de nouvelles connaissances en matière d'élaboration de lois et de mesures régissant les entreprises à vocation sociale dans l'avenir. Cet article commence par une description détaillée des diverses définitions que les États donnent du but des entreprises à vocation sociale et de celles qui ont une vocation semblable, notamment des expériences menées par les administrations, qui ont choisi tantôt un système d'homologation régi par l'État, tantôt des structures juridiques organisationnelles distinctes pour répondre aux exigences croissantes de secteurs et d'intervenants particuliers. On conclut que la plupart des administrations demandent aux entreprises à vocation sociale d'avoir un but social précis, défini en fonction des besoins ciblés de secteurs, de populations vulnérables ou de groupes marginalisés particuliers. On examine ensuite comment les nouvelles lois nationales tentent de faciliter ou de restreindre l'accès des entreprises à vocation sociale aux capitaux. Enfin, on donne un aperçu détaillé de diverses initiatives fiscales étudiées par les États pour promouvoir les entreprises à vocation sociale. Il est suggéré aux législateurs d'être prudents dans l'élaboration de lois régissant les entreprises à vocation sociale, surtout lorsqu'ils le font en réaction à des groupes d'intérêts privés, et de prendre part à des débats approfondis sur les moyens légaux à leur disposition pour promouvoir les entreprises à vocation sociale dans leur territoire administratif.

\section{INTRODUCTION}

The past three decades have witnessed a notable rise in self-proclaimed "social enterprise" businesses around the world. ${ }^{1}$ Following on the heels of this global business trend, a new strain of corporate law is emerging on the global stage. Policymakers and legislative bodies are experimenting with new legal tools to guide the private sector towards producing social outputs while relieving burdens on the public purse. New laws designed to foster and govern social enterprises are propagating throughout the world. ${ }^{2}$ Beyond American initiatives, relatively little has been written to date on the global contagion of lawmaking to address the burgeoning field of social enterprise. ${ }^{3}$ The lion's share of research coming out of this emerging

1 Dimple Agarwal et al, "The Rise of the Social Enterprise: 2018 Deloitte Global Human Capital Trends" (28 March 2018), online: Deloitte Insights <www2.deloitte.com/insights/us/en.html>; Janelle A Kerlin, "A Comparative Analysis of the Global Emergence of Social Enterprise" (June 2010) 21:2 Voluntas: International J Voluntary and Nonprofit Organizations 162. Social Enterprise Canada has attributed the rapid growth of social enterprises to: (1) the general understanding that there are some needs the market will never meet on its own; (2) the opportunity for entrepreneurs to advance mission-related goals; (3) the diminished and changing nature of government funding; and (4) the promise of social enterprise as a vehicle for social innovation. Cathy Lang et al, "The Canadian Social Enterprise Guide, 2nd edition" (August 2010), online: Ontario Council of Agencies Serving Immigrants $<\mathrm{http}$ :/dev.orgwise.ca>.

2 Borrowing terminology inspired by Natasha Affolder, "Contagious Environmental Lawmaking" (Inaugural Lecture at the Peter A Allard School of Law, University of British Columbia, 20 November 2018); see also Toby S Goldbach, "Legal Norms' Distinctiveness in Legal Transplants and Global Legal Pluralism" (2013), online: Allard Research Commons $<$ https://commons.allard.ubc.ca $>$.

3 For example, The Cambridge Handbook for Social Enterprise Law focuses mainly on initiatives in the United States and the benefit corporation, in particular, with C Liao and N Boeger as the only non-US contributing authors. Benjamin 
field has been dominated by analysis of the American benefit corporation, as American entrepreneurs behind the private B Corporation certification have actively lobbied for this legal structure in other countries, ${ }^{4}$ forcing an American framing of the issues. ${ }^{5}$ Increased attempts by B Corporation to transplant benefit corporation legislation into other countries, ${ }^{6}$ with little sensitivity towards existing legal ecosystems within those nations, ${ }^{7}$ has generated an urgency to broaden the literature and unearth the wide range of social enterprise law initiatives occurring throughout the world. In particular, developments in Asia have been absent from much of the Anglo-American scholarship. ${ }^{8}$ The discussions that are beginning to take shape among politicians and industry leaders with respect to the social enterprise lawmaking phenomenon are multifaceted, nuanced, and occasionally based more on conjecture than probative research. ${ }^{9}$ This article distinguishes this international movement while identifying critical thematic issues from the available data, in hopes of shifting the focus away from the American benefit corporation in Canada and other countries, and adding new knowledge to the development of social enterprise law and policymaking in the years ahead.

The term "social enterprise" itself has a variety of meanings within and across nations and sectors, which can be a source of frustration (and abuse) for entrepreneurs as well as for governments, stakeholders, and researchers. ${ }^{10}$ Yet even states with vastly different legal and political systems - from

Means \& Joseph Yockey, eds, The Cambridge Handbook for Social Enterprise Law (Cambridge, UK: Cambridge University Press, 2018). As well, the benefit corporation is named as the "current front runner" in social enterprise law in Dana Brakman Reiser \& Steven Dean, Social Enterprise Law: Trust, Public Benefit, and the Capital Markets (Oxford: Oxford University Press, 2017), ch 3: "Evaluating the Current Menu of Legal Forms," with the US low-profit limited liability company and other state off-shoots of the benefit corporation identified as other existing alternatives, and the United Kingdom's community interest company (CIC) noted as an international model that is "very different," but no other international initiatives are identified. For Canadian analysis on the benefit corporation, see Carol Liao, "A Critical Canadian Perspective on the Benefit Corporation" in "The Benefit Corporation and the Firm Commitment Universe" (2017) 40:2 Seattle UL Rev 683; Richard Janda, Richard Lehun \& Philip Duguay, "The Rise of the Benefit Corporation: Is This a Future for the Firm?" (20 January 2018), online: Social Sciences Research Network<papers.ssrn.com>.

4 See B Lab, "International Legislation" (last visited May 2019), online: Benefit Corporation $<$ benefitcorp.net/international-legislation> [B Lab, "International Legislation"]; see also Carol Liao, "BC MLAs Should Recognize 'Benefit Corporation' Is an American Branding Exercise," Globe and Mail (21 October 2018), online: $<$ www.theglobeandmail.com/> [Liao, "BC MLAs"].

5 For example, in Canada, see Liao, "BC MLAs," supra note 4.

6 B Corporation is lobbying Canada, Australia, Argentina, and Chile (with legislation already enacted in Italy and Puerto Rico). Ibid.

7 See e.g. Alessio Bartolacelli, "The Unsuccessful Pursuit for Sustainability in Italian Business Law” in Beate Sjåfjell \& Christopher Bruner, eds, The Cambridge Handbook for Corporate Law, Corporate Governance and Sustainability (forthcoming 2019). Italy has a very strong cooperative and social cooperative sector, see Paul Gosling, "Social Cooperatives in Italy: Lessons for the UK" (2011), online: <http://socialeconomyaz.org/>.

8 See e.g. Means \& Yockey, supra note 3; Dana Brakman Reiser, "Theorizing Forms for Social Enterprise" (2013) 62:4 Emory LJ 681; Janelle A Kerlin, "Social Enterprise in the United States and Europe: Understanding and Learning from the Differences" (2006) 17:3 Intl J Voluntary \& Nonprofit Organizations 247. A notable exception is Jacques Defourny \& Marthe Nyssens, "Mapping Social Enterprise Models: Some Evidence from the 'ICSEM' Project" (2017) 13:4 Social Enterprise J 318.

9 See e.g. multiple statements by Andrew Weaver, Member of Legislative Assembly, BC Green Party, touting the benefits of adding benefit company legislation to British Columbia, Canada. Andrew Weaver, "Bill M209: Business Corporations Amendment Act, 2019" (29 April 2019), online: Andrew Weaver, $M L A<\mathrm{http} / / / \mathrm{www}$.andrewweavermla.ca/>. Yet empirical research has shown a substantial portion of benefit corporations are not evidently delivering any social or environmental benefits. Ellen Berrey, "Social Enterprise Law in Action: Organizational Characteristics of US Benefit Corporations" (2018) 20:1 Tennessee J Business L 21.

10 E.g., the Overseas Development Institute, an independent global think tank, notes how "[f]rom a research perspective, it is obviously important to know what is the subject of research and what are the boundaries which define the research 
Britain, to Bolivia, to Vanuatu - are signaling their recognition that social enterprises "have a distinct and valuable role to play in helping create a strong, sustainable and socially inclusive economy," 11 along with their desires to "recognize, encourage and strengthen this sector that generates jobs and income." 12 The proliferation of self-named social enterprises may have direct and indirect implications on creating and diverting access to finance, human resources, marketing, and operations. If governments and donors want to extend some form of preferential treatment towards certain types of social businesses, clarification is ideal. States are attempting to create new legal infrastructure to help identify, govern, and channel resources towards certain social enterprise-type businesses, particularly in the form of legal certifications and/or separate corporate legal structures, which is the focus of this article.

Over 40 legal initiatives to support social enterprises implemented or pending in 30 countries throughout the world have been identified for this article. The global social enterprise lawmaking phenomenon is serving as a live experiment, providing opportunities for entrepreneurs seeking to house social enterprises while also attempting to counterbalance private sector negative externalities and affirm that "the independence of social value and commercial revenue creation is a myth." 13 Certain social enterprise laws contain features that are purposefully meant to attract those entrepreneurs situated within a particular sector, be it for-profit, non-profit, or otherwise. Conceptual boundaries are being tested as social enterprise laws begin to grow in recognition around the world. Table 1 lists the various social enterprise legal certifications and structures available throughout the world.

Table 1: Social Enterprise Law by the Numbers

\begin{tabular}{llcl}
\hline Name & Country & Start date & $\begin{array}{l}\text { Estimated } \\
\text { number }\end{array}$ \\
\hline \multicolumn{2}{l}{ Alternative cooperatives (including legal certification cooperatives) } & \\
Social cooperative & Italy & 1991 & $21,600^{\mathrm{a}}$ \\
Social solidarity cooperative & Portugal & 1996 & $180^{\mathrm{b}}$ \\
Social initiative cooperative & Spain & 1999 & $566^{\mathrm{c}}$ \\
Limited liability social cooperative & Greece & 1999 & $24^{\mathrm{d}}$ \\
Société cooperative d'interet collectif & France & 2001 & $692^{\mathrm{e}}$ \\
$\begin{array}{l}\text { Social cooperative (form of work } \\
\text { integration social enterprise) }\end{array}$ & Poland & 2006 & $1,269^{\mathrm{f}}$ \\
Community service cooperative & Canada & 2007 & $386^{\mathrm{g}}$ \\
Social cooperative enterprise & Greece & 2011 & $530^{\mathrm{h}}$ \\
Social cooperative & South Korea & 2012 & $1,200^{\mathrm{i}}$ \\
\hline Other legal certifications & & & \\
Private institutions of social solidarity & Portugal & 1983 & $5,148^{\mathrm{j}}$ \\
\hline
\end{tabular}

topic. From the point of view of governments, donors and promoters, it is important to know what it is meant by social enterprise so that regulation and support is properly targeted and also tailored to the needs of the targeted enterprises." Overseas Development Institute (last visited May 2019), online: About ODI<www.odi.org/about-odi>.

11 "Social Enterprise: A Strategy for Success" (July 2002), online: $F A F<$ www.faf-gmbh.de $>$.

12 Constitution of the Republic of Ecuador (2008), art 283; Organic Law on Popular and Solidarity Economy and the Popular and Solidarity Financial Sector (2012); see also Portugal's framework law, which recognizes and seeks to encourage socially beneficial commerce under the Social Economy Law, No 68/XII (13 March 2013). The social economy has legal recognized constitutional status (e.g., art 82 of the Constitution, which recognizes the coexistence of three economic sectors, including the social and cooperative sector).

13 Julie Battilana et al, "In Search of the Hybrid Ideal" (2012) 10:3 Stanford Social Innovation Rev 51. 


\begin{tabular}{|c|c|c|c|}
\hline $\begin{array}{l}\text { Social finality company / Verbond sociale } \\
\text { ondernemingen }\end{array}$ & Belgium & 1995 & $737^{\mathrm{k}}$ \\
\hline Social enterprise & Finland & 2003 & $154^{1}$ \\
\hline Work-integrated social enterprise & Lithuania & 2004 & $187^{\mathrm{m}}$ \\
\hline Social enterprise ex-lege & Italy & 2006 & $1,348^{\mathrm{n}}$ \\
\hline Social enterprise & South Korea & 2006 & $2,030^{\circ}$ \\
\hline Work integration social enterprise & Spain & 2007 & $204^{p}$ \\
\hline Community business & South Korea & 2010 & $1,514^{\mathrm{q}}$ \\
\hline Social enterprise & Slovenia & 2011 & $259^{r}$ \\
\hline Special employment centre & Spain & 2013 & $450^{\mathrm{s}}$ \\
\hline Social enterprise & Denmark & 2014 & $260^{t}$ \\
\hline Entreprise solidaire d'utilité sociale & France & 2014 & $967^{\mathrm{u}}$ \\
\hline Enterprise & Vietnam & 2014 & $1,000^{\mathrm{v}}$ \\
\hline Social enterprise & Thailand & 2016 & $1,007^{\mathrm{w}}$ \\
\hline \multicolumn{4}{|l|}{ New separate legal structures } \\
\hline Social welfare enterprise (shehui ban) & China & 1949 (original) & $23,000^{x}$ \\
\hline Community interest company & United Kingdom & 2005 & $16,231^{\mathrm{y}}$ \\
\hline Low-profit limited liability company & United States & 2008 & $1,266^{\mathrm{z}}$ \\
\hline Community company & Solomon Islands & 2009 & $52^{\text {aa }}$ \\
\hline Community company & Vanuatu & 2009 & Unavailable \\
\hline Benefit corporation & United States & 2010 & $7,704^{\mathrm{bb}}$ \\
\hline Ejido & Mexico & $1917 / 2012$ & Unavailable ${ }^{\mathrm{cc}}$ \\
\hline Community contribution company & Canada & 2013 & $59^{\mathrm{dd}}$ \\
\hline Società benefit & Italy & 2016 & $100^{\text {ee }}$ \\
\hline \multicolumn{4}{|l|}{ Other } \\
\hline Subgroup of non-profit law & Japan & 1998 & Unavailable \\
\hline Civilian-run educational institute & China & 2004 & Unavailable \\
\hline $\begin{array}{l}\text { Limited company with distribution } \\
\text { restriction and foundation forms }\end{array}$ & Sweden & 2006 & $101^{\mathrm{ff}}$ \\
\hline
\end{tabular}

Source: Adapted from Carol Liao, "Social Enterprise Law: Friend or Foe to Corporate Sustainability?" in Beate Sjåfjell \& Christopher Bruner, eds, The Cambridge Handbook for Corporate Law, Corporate Governance, and Sustainability [forthcoming]. Framework and pending legislation are not included here; our methodology included local legislation that enabled for-profit entities to have a social mandate. Afterwards, we would research business registries and censuses to retrieve the most up-to-date data.

Notes:

a As of 2018. Italian Government (last visited May 2019), online: Ministry of Economic Development $<$ www.dati.mise.gov.it $>$.

${ }^{b}$ As of 2018. Seguranca Social (Portugal), search term "Listagem cooperativas," online: <www.seg-social.pt $>$.

${ }^{c}$ As of 2014. "Social Enterprises and Their Eco-Systems: A European Mapping Report - Updated Country Report: Spain" (2016) at 22, online: European Commission <https://ec.europa.eu/>.

d As of 2014. "Social Enterprises and Their Eco-Systems: A European Mapping Report - Country Report: Greece" (2014) at 18, online: European Commission <https://ec.europa.eu/>.

e As of 2018. "Sociétés coopératives d'intérêt collectif," online: Les SCIC <www.les-scic.coop>.

${ }^{\mathrm{f}}$ As of 2014. "Social Enterprises and Their Eco-Systems: A European Mapping Report - Updated Country Report: Poland" (2016) at 9, online: European Commission <https://ec.europa.eu/>.

g As of May 2019. Number of active community service cooperatives by province: 53 in British Columbia (BC Registry and Online Services - emailed confirmation); 37 in Manitoba (Entrepreneurship Manitoba: Companies Office - emailed confirmation); 296 in Saskatchewan (Office of Public Registry Administration - emailed 
confirmation).

h As of 2014. "Social Enterprises and Their Eco-Systems: A European Mapping Report - Country Report: Greece" (2014) at 17, online: European Commission <https://ec.europa.eu/>.

${ }^{i}$ As of 2016. Anna Triponel \& Natalia Agapitova, "Legal Framework for Social Enterprise: Lessons from a Comparative Study of Italy, Malaysia, South Korea, United Kingdom, and United States" (2017), online: Documents \& Reports $<$ documents.worldbank.org/curated/en/home $>$.

j As of 2018. Seguranca Social (Portugal), search term "Listagem IPSS," online: <www.seg-social.pt>.

k As of 2014. "Social Enterprises and Their Eco-Systems: A European Mapping Report - Country Report: Belgium" (2014) at 20, online: European Commission <https://ec.europa.eu/>.

${ }^{1}$ As of 2009. "Social Enterprises and Their Eco-Systems: A European Mapping Report - Country Report: Finland" (2014) at 31, online: European Commission <https://ec.europa.eu/>.

m As of 2018. Laima Okuneviciute Neverauskiene \& Irena Pranskeviciute, "Overcoming Paradox for Social Enterprise Definition: Case of Lithuania" (2018) 12:1 Ekonomicko-Manazerske Spektrum 104 at 110.

${ }^{n}$ As of 2011. "Social Enterprises and Their Eco-Systems: A European Mapping Report - Updated Country Report: Italy" (2016) at 29, online: European Commission $<$ https://ec.europa.eu/>.

${ }^{\circ}$ As of 2018. Korea Social Enterprise Promotion Agency, "Korea Social Enterprise Promotion Agency," online: $<$ www.socialenterprise.or.kr>.

p As of 2014. "Social Enterprises and Their Eco-Systems: A European Mapping Report - Country Report: Spain" (2014) at 21, online: European Commission <https://ec.europa.eu/>.

q As of 2018. "Annual Report on Administrative Safety Statistics" (2018), online: Ministry of Security and Public Administration $<\mathrm{http}: / /$ www.mois.go.kr>.

${ }^{r}$ As of 2018. Republic of Slovenia Minstrstvo Za Gospodarski Razvoj in Technologijo (2018), online: $<$ www.mgrt.gov.si>; see also Majda Gartner et al, Social Entrepreneurship in Slovenia: State of the Art Report (GeaCollege, 2017) at 11.

s As of 2014. "Social Enterprises and Their Eco-Systems: A European Mapping Report - Country Report: Spain" (2014) at 22, online: European Commission $<\mathrm{https}: / /$ ec.europa.eu/>.

${ }^{t}$ As of 2018. Registreret Socialøkonomisk Virksomhed, online: $<$ www.ft.dk>; see also "Social Enterprises and Their Eco-Systems: A European Mapping Report - Country Report: Denmark" (2014) at 20, online: European Commission $<\mathrm{https} / / / \mathrm{ec}$.europa.eu/>.

"As of 2017. "Les entreprises agréées ESUS : quelle réalité aujourd'hui ?" Avise.org (2017) online: Avise $<$ www.avise.org>; see also "Social Enterprises and Their Eco-Systems: A European Mapping Report - Updated Country Report: France" (2016) at 27, online: European Commission $<$ https://ec.europa.eu/>.

v As of 2016. Anh Truong \& Jo Barraket, "Engaging Workers in Resource-Poor Environments: The Case of Social Enterprise in Vietnam" (2018) 29:20 International Journal of Human Resource Management 1 at 6; see also Thang V Pham, Huyen Nguyen \& Linh Nguyen, "Social Enterprise in Vietnam" (2016) International Comparative Social Enterprise Models Working Paper No 31 at 6.

w Nuttaphong Jaruwannaphong, "Social Enterprises in Thailand" (2016) at 13, online: World Fair Trade Organization - Asia $<$ https://wfto-asia.com/>.

${ }^{x}$ As of 2008. Xiaomin Yu, "Social Enterprise in China: Driving Forces, Development Patterns and Legal Framework" (2011) 7:1 Social Enterprise Journal 9.

y Twitter account of the Office of the Regulator of Community Interest Companies, see @CICRegulator, "At the Start of Today There Are 16,231 \#CICs on the Public Record" (28 May 2019), online: Twitter $<$ https://twitter.com/cicregulator>.

${ }^{z}$ As of 2017. Sonia J Toson, "Renewed Hope for the Low-Profit Limited Liability Company" (2018) 13:1 Society and Business Review 100 at 107.

${ }^{\text {aa }}$ As of 2018. Companies Act 2009 (Solomon Islands), Part 4.

bb As of 2018. Ellen Berrey, "Social Enterprise Law in Action: Organizational Characteristics of U.S. Benefit Corporations" (2018) 20:1 Tennessee Journal of Business Law 21; see also James Woulfe, "How Many Benefit Corporation Are There in the U.S?" (19 June 2018), online: SocEntPolicy <www.socentpolicy.com/>, indicating that there are only 5,389 benefit corporations in the United States.

cc Carola Conde, "Social Enterprise in Mexico: Concepts in Use in the Social Economy" (2015) International Comparative Social Enterprise Models Working Paper No 22.

dd As of May 2019. Number of active Community Contribution Companies by province: 59 in British Columbia (BC Registry and Online Services - emailed confirmation); Laina Smith, "Privately-Owned Companies in Canada 
Currently Best for Public Benefit Missions" (7 March 2018), online: Blaney Mcmurtry LLP <www.blaney.com> noting $70 \mathrm{C} 3 \mathrm{~s}$ in $\mathrm{BC}$ and five community interest companies in Nova Scotia.

${ }^{e e}$ As of 2017. EVPA's National Policy Nexus-Società Benefit in Italy (2017).

${ }^{\mathrm{ff}}$ As of 2010. "Social Enterprises and Their Eco-Systems: A European Mapping Report - Country Report: Sweden" (2014) at 17, online: European Commission $<$ https://ec.europa.eu/>.

As seen in Table 1, the number of businesses registered or incorporated for each of the various certifications and structures, with three exceptions, ${ }^{14}$ remain in the low thousands. ${ }^{15}$ Thus, while selfidentified social enterprises have risen considerably in world markets, ${ }^{16}$ the number of entrepreneurs and businesses willing to utilize new social enterprise laws are minimal when compared to other corporate forms. However, these laws are still relatively new (with most implemented in the past decade), and the utility of social enterprise law to date remains an open question. ${ }^{17}$ Furthermore, the numbers may not be a focal point so much as creating vehicles that are purposefully targeted to address the needs of special and/or marginalized populations. ${ }^{18}$ Whether or not the low numbers should be regarded as a concern depends on the goals these laws are aimed to achieve.

This article begins in Part II by detailing various ways in which states have defined the purpose of social enterprise and social enterprise-type businesses. Part III then identifies how jurisdictions have experimented between state-run certifications and separate corporate legal structures to meet the growing demands from particular sectors and stakeholders. An additional tension is observed with non-state actors attempting to gain market share of social businesses by creating recognizable consumer brands with private certifications and, in the case of the American B Corporation, lobbying states to create legal structures supporting their private brand. Part IV addresses the capitalization of social enterprises, including how social finance has developed alongside social enterprise and how new legislation has sought to ease or restrict capital access for these enterprises. Part V then examines the issue of social enterprise taxation. Tax incentives are a continually pertinent question for legislators; this section provides a detailed overview of the options explored by governments throughout the world. We conclude by suggesting that lawmakers proceed with caution in the development of social enterprise laws, particularly when they are in response to private interest groups, and engage in fulsome discussions on the range of available legal methods to foster social enterprise within their jurisdictions.

\section{PURPOSE OF SOCIAL ENTERPRISE VIA LAW}

In jurisdictions where the term "social enterprise" has no formal legal meaning, it has been used quite broadly - and, at times, opportunistically - by industry. ${ }^{19}$ Diverse state and non-state actors have viewed social enterprises as encompassing, inter alia: (1) enterprising non-profits, which can be considered as

14 These exceptions are the UK CIC, which began in 2005 and, as of November 2018, has 15,217 registered CICs, surpassing the number of cooperatives in that country; the Italian social cooperative, implemented in 1991, which was the first of its kind in Europe and part of a broader successful cooperative culture in that country, with over 21,600 in existence; and the Chinese shehui ban with 23,000 in existence.

15 Many states do not formally track, or make publicly available, the number of businesses adhering to various legal forms and certifications. Numbers shown are based on the best available data from primary and secondary sources, including attempting to contact state departments for the latest available numbers.

16 See Agarwal, supra note 2.

17 See Carol Liao, "Early Lessons in Social Enterprise Law" in Means \& Yockey, supra note 3, 101 [Liao, "Early Lessons"].

18 Discussed in subpart I.B.

19 Sean Barnes \& Steven Moe, "Four Ways to Save a Social Enterprise from Social-Washing” (26 July 2018), online: Medium $<$ https://medium.com/>. 
non-profit organizations [NPOs] that are "exploring the development of business activities for the dual purposes of generating revenue and furthering their mission"; $; 2$ (2) businesses "whose primary purpose is the common good"; ${ }^{21}$ and/or (3) a corporate group formation of these two entities. In fact, states have allowed for the recognition of an array of social enterprise-type businesses with the development of new legal certifications where businesses can become certified using any existing legal structure, along with entirely new structures, including instances where the actual term "social enterprise" has been given its own legal form or certification. In most jurisdictions, the purpose of these social enterprises is explicitly defined under the law, as discussed in subpart II.A, and, in others, there is a range of ability for these businesses to design their own self-constructed purpose within certain parameters, as discussed in subpart II.B.

\section{A. Purpose Explicitly Defined by Law}

In Asia, since many governments started moving away from a centralist regime, more of them have begun adopting public policies of contracting with NPOs, leading them to seek more market-oriented approaches, redefine the term "social enterprise," and create infrastructure to support new certifications. ${ }^{22}$ Asia has been bold in its experimentation. ${ }^{23}$ Countries including South Korea, Vietnam, and Thailand are testing different social enterprise law initiatives to foster education, agriculture, and the improved livelihood of communities. Malaysia has been particularly adventurous in experimenting with social incubators and other methods of training social entrepreneurs. ${ }^{24}$ Other countries such as the Philippines are putting forth new legislation to utilize the social enterprise form as a tool for poverty reduction. ${ }^{25}$

South Korea, Vietnam, and Thailand have implemented their own social enterprise laws with the aim of promoting employment and/or developing local communities, societies, or protecting the environment. ${ }^{26}$ South Korea's Social Enterprise Promotion Act of 2006 has made "social enterprise" a legally protected title, defined as an organization "producing and selling goods and services while pursuing a social purpose of enhancing the quality of local residents' life by means of providing social services and creating jobs for the disadvantaged," with five categories of job creation, social services, mixed type, local community contribution, and a discretionary category. ${ }^{27}$ Any legal form may qualify for certification as long as the business abides by a range of prescribed requirements, including an asset lock and the reinvestment of profits towards the social purpose.

In 2014, Vietnam created a certification for businesses seeking to resolve social or environmental issues for the interests of the community, with at least 51 percent of profits required to be reinvested for its state-

20 "Enterprising Non-Profits Toronto" (2018), online: Centre for Social Innovation $<$ http://socialinnovation.ca/enp $>$.

21 "Why Goodness Should Be a Core Value in Every Business" (18 December 2015), online: Social Enterprise Alliance $<$ www.se-alliance.org $>$. Social Enterprise Alliance defines social enterprises as businesses that "use the methods and disciplines of business and the power of the marketplace to advance their social, environmental and human justice agendas." Ibid.

22 Xiaomin Yu, "Social Enterprise in China: Driving Forces, Development Patterns and Legal Framework" (2011) 7:1 Social Enterprise Journal 9; Bindu Sharma, Contextualising CSR in Asia: Corporate Social Responsibility in Asian Economies (Singapore: Lien Centre for Social Innovation, 2013) at 200.

23 See e.g. Azlan Amran \& AK Siti Nabiha, "Corporate Social Reporting in Malaysia: A Case of Mimicking the West or Succumbing to Local Pressure" (2009) 5:3 Social Responsibility J 358.

24 See Malaysian Global Innovation \& Creativity Centre (last visited May 2019), online: MaGIC <www.mymagic.my>.

25 Poverty Reduction through Social Entrepreneurship Act (pending legislation) (Philippines).

26 See e.g. Social Enterprise Promotion Act, No 8217 (2007) (Korean); "Maeul-kieop" - that is, a community business system - Ministry of Security and Public Administration (South Korea), online <www.mois.go.kr/eng>; Framework Act on Cooperatives, Act No 11211 (6 January 2012).

27 Social Enterprise Promotion Act 2006 (South Korea). 
registered purpose. ${ }^{28}$ In Thailand, in order for a business to attain the government-issued social enterprise certification, it must also reinvest at least 70 percent of profits back into the business or for the benefit of farmers, the poor, disabled, disadvantaged, or other common benefits, as prescribed by Thailand's Ministry of Finance. ${ }^{29}$ Certified social enterprises in Thailand must also include "social enterprise" in their name. ${ }^{30}$

In the Middle East, Israel was an early leader when it created in 1999 a new legal form - chevrah leto'elet hatzibur (public benefit company), which is more commonly known by its acronym "chalatz." 31 This share company is required to pursue one of 13 public benefit purposes, which include benefits to the environment, health, religion, animal protection, human rights, education, science, sport, immigration, charity, community welfare, law, or other activities enumerated under the statute. ${ }^{32}$ It must also include "PBC" in its name, indicating it is a public benefit company. ${ }^{33}$ The distribution of profit and assets upon dissolution to shareholders are prohibited, and shares may not be transferred unless authorized by the court. ${ }^{34}$ In South America, Chile is establishing bodies to explore financing and marketing aspects of social enterprise as a cautionary move before enacting laws for any possible new legal forms. ${ }^{35}$ Other countries, such as Russia ${ }^{36}$ and Australia, ${ }^{37}$ indicate that they are following suit.

In Europe, seven states have created social cooperatives that range in purpose from specific targeted purposes, such as the promotion and integration of disadvantaged people ${ }^{38}$ or the employment of people with disabilities, ${ }^{39}$ to slightly broader social purposes, such as benefiting health, education, culture, work integration, or social inclusion. ${ }^{40}$ In France, the Société cooperative d'interet collectif [SCIC] comprises commercial enterprises - limited liability companies or joint-stock companies - whose objective is production or supply of goods and services having general interest and offering social benefit. SCICs must pursue a commercial purpose that relates to a social purpose that benefits the community, and the definition of "social purpose" is focused on providing assistance to vulnerable persons or activities that remedy discrimination or inequalities within society. ${ }^{41}$ France also offers two state certifications, entreprise de l'économie sociale et solidaire [ESS] and entreprise solidaire d'utilité sociale [ESUS], where businesses can obtain these certifications by adhering to a number of requirements, including a reinvestment of the majority of the profit into the company's activities with a focus on providing assistance to vulnerable persons or activities that remedy discrimination or inequalities within society. ${ }^{42}$

28 Law on Enterprises, Law No 68-2014-QH13 (2014); Decree 69/2008/ND-CP.

29 CIT Exemption: Social Enterprise, RD No 621, BE 2559 (2016); Social Enterprise Promotion Act (pending).

30 A social enterprise cannot pay dividends, a share of profits, or income from capital reduction to shareholders or partners and cannot transfer property, except as prescribed by the Director-General.

31 Companies Law, Law 5759-1999 (1999) (Israel), s 345.

32 Ibid.

33 Ibid at $345 \mathrm{D}(\mathrm{a})$.

34 Ibid.

35 Rosa Castizo \& Heloise Buckland, "Study of Social Entrepreneurship and Innovation Ecosystems in the Latin American Pacific Alliance Countries" (July 2016), online: Inter-American Development Bank <https://www.iadb.org/en>.

36 Natalia Agapitova, Creating Competitive Markets for Service Delivery: Policy Options and Country Experiences (Washington, DC: World Bank Group, 2017).

37 Jo Barraket, Chris Mason \& Blake Blain, "Finding Australia's Social Enterprise Sector 2016: Final Report” (June 2016), online: ResearchGate <www.researchgate.net/>.

38 Cooperative Code, Law 51/96 (1996); Legislative Decree No 7/98 (1998) (Portugal).

39 Act on Social Enterprises, Law 1351/2003 (2003) (Finland).

40 Law 27/1999 (1999), art 106 (Spain).

41 Law No 2001-624 (2001) (France).

42 Entreprise solidaire d'utilité sociale (ESUSs) have two requirements in addition to those required by the Enterprise de l'entreprise de l'économie sociale et solidaire (ESS), which is that (1) the social purpose must have significant impact on 
The Italian social enterprise ex-lege state certification allows for any form of private business that permanently pursues a "public benefit" to certify, but the overly broad definition of public benefit is curtailed by limiting the meaning to benefiting certain sectors, including social assistance, health care, education, instruction, and training. ${ }^{43}$ Workers and beneficiaries must have a say in the governance of the social enterprise (which could be as simple as consultation), with the governance structure dictated by the legal form of that business. ${ }^{44}$ By comparison, the Portuguese private institutions of social solidarity [IPSS] is a state certification for "nonprofit institutions, created by private initiative, with the purpose of giving organized expression to the moral duty of solidarity and justice between individuals," and social/moral purposes include child and family support services, assisting disadvantaged groups, education and employment training, and social housing projects. ${ }^{45}$ Like the Italian social enterprise ex-lege, the certification may attach to many different legal forms as long as the state criteria are met.

Work-integrated social enterprises [WISEs] are popular in Europe, appearing in 12 countries with varying features. ${ }^{46}$ WISEs can be defined as "combin[ing] training and the development of skills of marginalized people within an enterprise that has social dimensions, and that trades in the market." ${ }^{47}$ For example, in Spain, WISEs employ persons at risk of "social exclusion," a situation that has to be accredited by the public social services responsible for each type of exclusion. ${ }^{48}$ Finnish WISEs are designed to encourage any kind of enterprise to employ people with disabilities and long-term unemployed persons, and no other Finnish enterprises may use the term "social enterprise" in marketing or business names. ${ }^{49}$

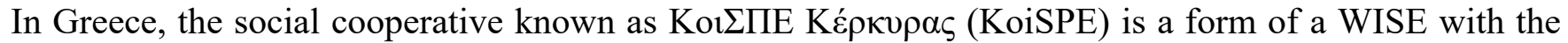
purpose of social-economic integration and labour market inclusion of persons with mental illnesses. ${ }^{50}$ The Lithuanian WISE certification may also attach to any legal form so long as activities are related to the employment of a targeted group, developing working and social skills as well as social integration. ${ }^{51}$

European governments require WISEs to register in some form with the state. WISEs have been integral in "providing resources of access, mutual help (social capital), and 'getting together' - very much as a way of helping socially excluded (marginalized) people with their coping strategies. Indeed in the way they operate as organisations they typically embrace a similarly diverse resource base for their own 'coping' strategies in market economies." 52 Jurisdictions have typically incorporated oversight for these new models and certifications into existing government infrastructure. For example, the Israeli chalatz must adhere to the same protocols as an NPO and applies to the Registrar of Charities to access any

its business (that is, at least $66 \%$ of business expenses are dedicated to social mission or rate of return on investment is less than 5.96\%); (2) average amount paid to five highest paid employees or executives cannot exceed seven times legal minimum wage, and highest paid employee or executive cannot exceed ten times the legal minimum wage.

43 Legislative Decree no 112/2017 (2017).

44 Ibid.

45 Law 1983/2007 (2007); Law-Decree No 119/83 (1983); Regulation No 139/207 (Portugal).

46 Countries include Austria, Belgium, Finland, France, Germany, Ireland, Italy, Luxembourg, Portugal, Spain, Sweden, and the United Kingdom. For a detailed comparative analysis, see Roger Spear \& Eric Bidet, "Social Enterprise for Work Integration in 12 European Countries: A Descriptive Analysis" (2005) 76:2 Annals of Public and Cooperative Economics 195.

47 Ibid at 197.

48 Law 44/2007 (2007) (Spain).

49 Requiring at least 30 percent of its employees to meet such a definition. Act on Social Enterprises, supra note 39.

50 Law No 2716/99 (1999) (Greece).

51 Forty percent of employees must be from that targeted group. Law on Social Enterprises, Law 1/6/2004 (2004, amended 2011) (Lithuania).

52 Spear \& Bidet supra note 46 at 201. 
governmental grants or tax exemptions. ${ }^{53}$ Poland includes their registration of social cooperatives under the purview of the Polish National Council for Cooperatives. ${ }^{54}$

Common themes emerge in our observation of these social enterprise laws where the purpose is explicitly defined under the law. All social enterprise laws in these jurisdictions include additional regulatory features that help ensure the purpose is locked into the organization - with virtually all of the social enterprise laws observed requiring that some amount of the profits be reinvested back into the organization in pursuit of that social purpose or some form of asset lock be used to restrict the transfer of assets for use outside its stated purpose. The reinvestment of profits is a common feature in informal state definitions of social enterprises as well. The United Kingdom's Department for Business Innovation and Skills has noted that a social enterprise "is a business with primarily social objectives whose surpluses are principally reinvested for that purpose in the business or in the community, rather than being driven by the need to maximise profit for shareholders and owners." ${ }^{55}$ The Canadian federal government has also provided non-legal definitions in the past, with the notable feature of social enterprise being that "the majority of net profits must be directed to a social objective with limited distribution to shareholders and owners." 56 This sentiment is in contrast to the United States, which has largely allowed the private sector to dominate and define the parameters of the social enterprise law movement. ${ }^{57}$ It should also be noted that the American benefit corporation, discussed in the next section and which has no such requirement of the reinvestment of profit, is often cited by American scholars as the foremost example of social enterprise law. ${ }^{58}$

\section{B. Self-Constructed Purpose}

In comparison to most state initiatives found in Asia and Europe that require a level of specificity on the social purpose, such as its impact on a particular sector or employment of people in marginalized groups, some jurisdictions have tended to employ laws that describe the purpose of the social enterprise generally, such as "community interest" or "public benefit," without detailing many parameters on what this purpose entails. In South Africa, a federal non-profit company has been created for the purpose of creating a public benefit. ${ }^{59}$ This non-profit company may carry on any business, trade, or undertaking consistent with, or ancillary to, its stated objectives; thus, "non-profit" is a misnomer. ${ }^{60}$ Small jurisdictions like the Solomon Islands and Vanuatu have also created a new community company legal form for social enterprise, where the principal objective is the promotion of any non-political community interest that a reasonable person would consider as benefiting the community. ${ }^{61}$ "Community" here means a group of

53 Shuy Fogel, “Defining a Chevrah LeTo'elet Hatzibur [Public Benefit Company]” (20 September 2010), online:

Nonprofit Banker $<$ http://nonprofitbanker.com>.

54 Act on Social Employment (2003); Law on Social Cooperatives (2003) (Poland).

55 "Social Enterprise: A Strategy for Success" (July 2002) at 7, online: $F A F<$ www.faf-gmbh.de $>$.

56 "Social Innovation and Social Finance Strategy: Consultation Document" (last visited May 2019), online: Government of Canada $<$ www.canada.ca/en.html $>$.

57 Janelle A Kerlin \& Kirsten Gagnaire, "United States” in Janelle A Kerlin, ed, Social Enterprise: A Global Comparison (Lebanon, NH: Tufts University Press, 2009).

58 See Means \& Yockey, supra note 3; Dana Brakman Reiser \& Steven Dean, "Creative Financing for Social Enterprise" (2014) 12:3 Stanford Social Innovation Review at 52.

59 Companies Act 71 of 2008 (South Africa).

60 As of 2014, this new form constituted 3.5 percent of non-profit organizations, with 4,446 registered. Pali Lehohla, "Statistics of the Non-Profit Sector for South Africa" in Statistics South Africa (2015) at 51.

61 Companies Act 2009 (Solomon Islands), Part 4 [Companies Act (Solomon Islands)]; see also Vijaya Nagarajan \& Terry Reid, "The Community Company as a Vehicle for Sustainability in the Solomon Islands: Hopes, Challenges and Possibilities" in Sjåfjell \& Bruner, supra note 7. 
individuals who share readily identifiable characteristics, and any shareholder must be a member of the relevant community and must be accountable to that community. ${ }^{62}$ These community companies cannot make any distribution of funds or pay any dividends to shareholders, nor make any loans to directors or shareholders. The community must receive the benefit, and there is a lock on the disposal of assets outside the ordinary course of business. ${ }^{63}$

The United Kingdom's community interest company [CIC] is a prominent example of laws allowing for a self-constructed purpose but with significant legislative oversight. To qualify for CIC status, interested parties must first pass a community interest test that is administered by the CIC regulator ${ }^{64} \mathrm{An}$ interested party satisfies the community interest test "if a reasonable person might consider that its activities (or proposed activities) are carried on for the benefit of the community." ${ }^{65}$ All interested parties applying for CIC status must provide the regulator with evidence that they will satisfy the community interest test, including providing a community interest statement and declaration that they are not engaged in political activities. The community interest statement must indicate that the company will carry on its activities for the benefit of the community and explain how those activities will indeed create a benefit. ${ }^{66}$ The regulator may elect not to allow a party to become a CIC if any of its activities benefit only the members of a particular body or the employees of a particular employer, without bringing any benefits (directly or indirectly) to a wider community. ${ }^{67}$ It is expected that the community will usually be wider than just the members of the CIC and can include either the community or population as a whole or a definable sector or group of people in the United Kingdom or elsewhere. The regulator may take enforcement action against a CIC if the regulator forms the view that the CIC no longer satisfies the test.

In the United States, one of the first attempts at social enterprise laws was the low-profit limited liability company [L3C], which was designed to house program-related investments [PRIs] under existing Internal Revenue Service [IRS] rules to enable foundations to better invest in PRIs without the fear of compromising their tax-exempt status. PRIs are sheltered from designation as jeopardizing investments if their primary purpose "is to accomplish one or more of the [organization's exempt] purposes ... and no significant purpose ... is [for] the production of income or the appreciation of property" or expenditures for political purposes. ${ }^{68} \mathrm{It}$ is important to note that the L3C was "not developed within state legislatures, but by a non-profit organization with a mission," ${ }^{69}$ as the Mannweiler Foundation had a heavy hand in its adoption by states. The $\mathrm{L} 3 \mathrm{C}$ was designed to make it easier for foundations to make PRIs, mirroring the language set forth in the IRS rules, including that the L3C would not have been formed but for its charitable or educational purpose, which is meant to assure foundations that their tax-exempt status will remain secure if they make a PRI in an L3C model.

The American benefit corporation has focused on utilizing non-state third-party measures to ensure the purpose of the social business is maintained. This feature may be driven by the fact that, like the L3C, an NPO has been the driver behind this legislation. B Lab is an NPO founded by entrepreneurs that provides

62 Companies Act (Solomon Islands), supra note 61, Part 4.

63 Ibid.

64 Companies Act 2006 (UK), c 46 [Companies Act (UK)]; Community Interest Company (Amendment) Regulations 2009 (UK), No 1788 [CIC Regulations (2009)].

65 CIC Regulations (2009), supra note 64, Reg 5.

66 Ibid, Reg 2.

67 Ibid, Reg 4.

68 Internal Revenue Code, ss 4944(c) and 4945. "Jeopardizing investments" under Internal Revenue Service rules can subject private foundations to considerably high excise taxes. Internal Revenue Manual Taxes on Investments Which Jeopardize Charitable Purposes (1998), s 7.27.18.

69 Brakman Reiser \& Dean supra note 3 at 62. 
the "B Corporation" certification to companies for fees, and has lobbied for benefit corporation legislation across the United States and in other countries. ${ }^{70}$ The purpose of the American benefit corporation is to create a general public benefit (or specific public benefit, as it is named in the articles), which is defined as "a material positive impact on society and the environment, as measured by a third-party standard, through activities that promote [some] combination of specific public benefits." 71 The Italian societá benefit, also formed due to the lobbying clout of B Lab, has similar requirements. ${ }^{72}$ The Canadian version of the benefit corporation, adopted in the province of British Columbia as of May 2019, has chosen a more watered down definition of public benefit, with only the requirement to "promote public benefit" and "public benefit" being defined to capture the vast majority of businesses that employ people or produce a good or service. ${ }^{73}$ A corporation seeking benefit corporation status must include or make a clear and prominent statement in its articles of incorporation that it is a benefit corporation. There are no specific criteria to qualify as a benefit corporation so long as proper company approvals have been met, and this also applies if a company wishes to withdraw from being a benefit corporation. As for what constitutes a third-party standard via benefit corporations, states have defined it as "a standard for defining, reporting, and assessing overall corporate social and environmental performance" and have allowed benefit corporations to self-determine how that third-party standard is conceived and met. ${ }^{74}$ Unlike other certifications and legal structures, there are no legal features requiring a reinvestment of profit or other economic constraints built into the benefit corporation to ensure that the social purpose of the business is maintained; these features would only be voluntary as they would for any corporation.

The developments in the United States highlight a trend towards private enterprise lobbying for new legal structures that tend to shift the power of defining purpose to non-state actors, with little to no ability for proper regulatory oversight or legal remedies upon any deviation of that purpose. The Italy and Canadian versions of the American benefit corporation are following the American lead on this trend. On the other hand, other state-created legal structures that allow for a self-constructed purpose, such as the UK CIC and community companies in the Solomon Islands and Vanuatu, include accompanying features such as asset locks, dividend caps, profit reinvestment, and strict regulatory oversight to legally ensure that the purpose is ingrained within the company's mission. The UK government chose to establish a central CIC office and regulator to solidify the identity and legitimacy of that new legal form, which was a significant step in garnering a solid base of support and building momentum. However, the endeavour requires a level of financial commitment from the government. ${ }^{75}$ The UK CIC regulator's office is a good

70 See ibid at 60.

71 Main common features across several states echo Maryland and Vermont, thus these states are used as examples. Maryland Act (2010), s 5-6C-01(c); Vermont Act (2011), s 21.03(4). These states typically use B Lab, "Model Benefit Corporation Legislation" (2017), online: Model Legislation <www.bcorporation.net>. For a state-by-state comparison, see "Status Tool” (last visited May 2019), online: New York University Social Enterprise Law Tracker $<$ https://socentlawtracker.org/\#/bcorps>.

72 B Lab, "English Information" (last visited June 2019), online: Societa Benefit <www.societabenefit.net/>.

73 Specifically, section 51.991 states public benefit "means a positive effect, including of an artistic, charitable, cultural, economic, educational, environmental, literary, medical, religious, scientific or technological nature, for the benefit of (a) a class of persons, other than shareholders of the company in their capacity as shareholders, or a class of communities or organizations, or (b) the environment, including air, land, water, flora and fauna, and animal, fish and plant habitats." Section 51.991(2) then goes on to carve out any duties or liability protections for stakeholders. BC Bill M209 (2019).

74 See Mohsen Manesh, "Introducing the Totally Unnecessary Benefit LLC" (2019) 97:3 NCL Rev 603 at 657-661.

75 The question boils down to one of cost and commitment. The UK government chose to establish a central CIC office and regulator to solidify the identity and legitimacy of that new legal form, which was a significant step in garnering a solid base of support and building momentum. However, the endeavour requires a level of financial commitment from the government. There is a risk that if the model does not gain traction in practice, then there will be little point in appointing a regulator to regulate - as has been seen in the Canadian equivalent, where the province of Nova Scotia enacted a 
example of how a light-touch regulation can be effective, but if the cost to legitimacy is low, there may be little need for regulatory oversight. Depending on the circumstances, the existing infrastructure may be sufficient to regulate new social enterprise laws until such time as a special regulator is warranted.

\section{CERTIFICATION VERSUS STRUCTURE}

In each jurisdiction, legislators have chosen whether to offer legal certifications, implement new separate legal structures, ${ }^{76}$ or offer a plurality of options for social entrepreneurs. Legal structures are incorporating instruments that legally define the parameters under which the business may operate. Legal certifications, on the other hand, are legally protected titles conferred on entities, regardless of the act under which it is constituted, after voluntarily meeting, or committing to meet, certain requirements, typically through the entities' constating documents. Besides this difference, the parameters and requirements established under both structures and certifications are diverse and overlapping. What can be accomplished with a legal structure can be done, arguably, with a certification and vice versa. For example, the Solomon Islands' community company (structure) ${ }^{77}$ and the Belgian social finality company, also known as verbond sociale ondernemingen [VSO] (certification), both restrict distributions of profits, either completely (Solomon Islands) or heavily (Belgium). Both certifications and structures have initial start-up costs associated with any new legal regime and are generally subject to the same complaints, such as a lack of knowledge ${ }^{78}$ or familiarity with social enterprises. ${ }^{79}$

While fluid and open in nature, both legal structures and certifications have been designed to increase investors' confidence and protect consumers in interchangeable ways. For investors, such as governments and impact investors, both legal structures and certifications can provide predictability and certainty. Constructed purposefully, both methods can provide a guarantee that the money or benefits received will be used for the intended social purpose. For example, governments have accomplished this through conversion provisions (that is, provisions allowing a certain legal structure to convert into another structure) or dissolution restrictions within their laws. The Israeli chalatz and Belgian VSO, for example, both contain a conversion provision subject to similar restrictions on transferring capital. ${ }^{80}$ The use of conversion provisions will generally be more advantageous for social entrepreneurs who wish to eventually shed any capital restraints provided under social enterprise laws. Commentators have noted that the lower costs associated with social enterprises, combined with access to beneficial incentives, make social enterprises ripe for abuse, ${ }^{81}$ and providing less onerous conversion provisions could exacerbate this issue.

For consumers, both legal certifications and structures can assist in preventing "social washing," akin to "green washing," where a business focuses more on social advertising and marketing than on actual do-

Canadian CIC and regulator but has had minimal success to date.

76 Also referred to as separate legal entities, forms, or vehicles; for ease, these will be referred to as structures.

77 Companies Act (Solomon Islands), supra note 61, Part 4.

78 See e.g. Sean Markey et al, "Social Enterprise Legal Structure: Options and Prospects for a 'Made in Canada' Solution" (June 2011), online: AMSSA <www.amssa.org>; Lee Mannion "Lack of Awareness Holds Back British Business That Do Good - Industry," Thomson Reuters Foundation News (14 September 2018), online <www.reuters.com>.

79 European Commission, "Supporting Entrepreneurs and the Self-Employed - Social Entrepreneurship" (last visited May 2019), online: Employment, Social Affairs and Inclusion <https://ec.europa.eu/social/>.

80 Israel's Companies Law, No 5759-1999 (1999), s 345; Belgian Consolidated Code of Societies, art 667.

81 Ioannis Nasioulas "Why Social Enterprise in Greece Is a Modern Day Myth," Thomson Reuters Foundation News (4 May 2018), online: < news.trust.org/item/20180503162655-k4lv0/>. 
gooding. ${ }^{82}$ As discussed in Part I, these governments have utilized various regulatory measures such as legal name protection, ${ }^{83}$ monitoring bodies, and reporting requirements. ${ }^{84}$ These governments have also established legal remedies for stakeholders against non-compliant enterprises. ${ }^{85}$ The Belgian VSO certification provides the state, interested members of the public, or business partners with the right to apply to the court for a remedy, either dissolution or a remedy under the act in which the enterprise is incorporated, where the enterprise is suspect of being non-compliant. ${ }^{86}$ These features are particularly notable when compared to private certifications, which cannot establish public law remedies due to their private nature.

There seems to be a shifting trend towards state legal certifications, especially in Europe and Asia. Within Europe, the need to standardize cross-border commerce is a driving factor for certification as it is easier to implement than standardizing a corporate form. The European Parliament, for example, suggested a legal certification encompassing the entire European Union (EU) that would create "more visibility and foster a more coherent legal framework" for commerce between EU countries. ${ }^{87}$ While cross-border commerce may not necessarily be the goal in Asian markets, the social enterprise law trend began with legal structures, but, similar to Europe, is increasingly moving towards legal certifications. Vietnam, the Philippines, and South Korea offer state certifications, and Thailand and Malaysia have legislation pending. A part of this trend may be due to the proximity of the countries and the successes of certification in these areas. Countries have been open about learning from others' successes. ${ }^{88}$ Emerging markets, such as Columbia and Ecuador, are currently in the process of setting the groundwork for future social enterprise legislation through general framework laws. ${ }^{89}$ Despite not having an official legal status, social enterprises in India are excelling under the general label of "social enterprise" and "impact investing" within health sciences, presumably, in part, due to the profitable nature of that industry in

82 JJ McMurtry \& François Brouard, "Social Enterprises in Canada: An Introduction" (2015) 6:1 Canadian J Nonprofit \& Social Economy Research 6; see also Tina H Ho, "Social Purpose Corporations: The Next Targets for Greenwashing Practices and Crowdfunding Scams" (2015) 13:3 Seattle J Social Justice 935 at 937. For more on green washing, see Adeyemi Ademola Egbeleke, "Strategic Corporate Responsibility and Sustainability Performance Management Model" (2014) 4:2 J Management \& Sustainability 92.

83 See e.g. in Finland's social enterprises certification, the title is legally protected; Pekka Pattiniemi, "Social Enterprise Legislation in Finland" (June 2008), online: <http://atlas.ekonomiaspoleczna.pl>.

84 Monitoring occurs generally through having a regular and requiring enterprise to file reports and how their enterprise work towards its social purpose, for example, under Law 155/2006, Italy's social enterprise ex-lege must file a report on its finances and "social report" describing how the entity worked towards its social purpose. For more detail, see "Social Enterprises and Their Eco-Systems: A European Mapping Report - Updated Country Report: Italy" (2016) at 18, online: European Commission $<$ https://ec.europa.eu/>.

85 For example, the American benefit corporation permit's shareholders, directors, or any other person specified in the articles of the benefit corporation, can make a benefit enforcement proceeding. A benefit enforcement proceeding is a claim or action against a director or officer for failing to pursue the public benefit's purpose set forth in its articles or for violating any duty in the statute. See Vermont Benefit Corporations Act, Vt Stat (2011), tit 11A, s 21 at s 21.13(b). However, note that, as of May 2019, there have been no known claims under a benefit enforcement proceeding to date, suggesting ineffectual oversight. See also Mohsen, supra note 74.

86 Code of Societies (1999), art 667, online: <www.ejustice.just.fgov.be>.

87 European Commission (EC), Commission Resolution 2016/2237 Concerning the Commission on a Statute for Social and Solidarity-based Enterprises (5 July 2018), online: <www.europarl.europa.eu>.

88 Joseph Kaos Jr, “PM: Foster Social Enterprises,” The Star Online (14 May 2015), online: <www.thestar.com>.

89 For example, Columbia and Ecuador have implemented framework laws that have set the stage for legal infrastructure to support social enterprise. Law 454 (4 August 1998); Constitution of the Republic of Ecuador (2008), art 283; Organic Law on Popular and Solidarity Economy and the Popular and Solidarity Financial Sector (2012). 
general. ${ }^{90}$

\section{A. Competition from Private Certifications}

As briefly noted in subpart II.B regarding the American B Corporation, it is important to acknowledge the growth and influence of private certifications in the social enterprise law arena. These private sector certifications at times compete with state-run certifications and, in some jurisdictions, have wielded considerable influence in the manner to which social enterprise laws have been implemented.

The most influential private certification to date in a legal sense has been B Corporation, which has been actively trying to create a global brand for itself. ${ }^{91}$ In order to become a certified B Corporation, a company is first required to pass a B impact assessment, which surveys issues relating to accountability, employees, consumers, community, and the environment. ${ }^{92}$ Within an allotted time following certification, B Corporations must amend their articles of incorporation to require directors to consider more than just shareholder interests when carrying out their duties. ${ }^{93} \mathrm{~B}$ Lab actively markets its branding internationally, and, as of December 2018, it noted on its website that there are over 2,655 B Corporations in 60 countries. ${ }^{94}$ Given that B Lab is a private organization, it does not have the authority to manipulate existing legal structures. Nevertheless, in addition to marketing its own certification process, B Lab has actively lobbied American state governments and other nations to adopt the benefit corporation form. Benefit corporation legislation has since been enacted in 33 states and the District of Columbia, and six states are reportedly developing or considering such legislation. ${ }^{95} \mathrm{~B}$ Corporations that are certified in states with benefit corporation legislation are obliged to convert into benefit corporations within a certain period of time. ${ }^{96}$ Equally so, benefit corporations are strongly encouraged to privately certify as B Corporations, creating a unique market share for B Lab funneled from state laws. ${ }^{97}$

B Lab allows companies that are incorporated in states without this legislation to build stakeholder interests into a signed term sheet, with an understanding that if the company's resident state eventually creates a benefit corporation, the company will adopt benefit corporation status by the end of their certification term. ${ }^{98}$ B Lab's heavy promotion of its certification outside of its country is notable. B Lab

90 Nita Bhalla, “Investment in India’s Social Enterprises Could Rise Eight-Fold to \$8bln by 2025: Research" (17 November 2016), online: Reuters <www.reuters.com>.

91 B Lab, “Certification” (last visited May 2019), online: Certified B Corporation <bcorporation.net/> [B Lab, "Certification"].

92 B Lab (last visited May 2019), online: B Impact Assessment < bimpactassessment.net/>.

93 B Lab, "Legal Requirements" (last visited May 2019), online: Certified B Corporation <www.bcorporation.net> [B Lab, "Legal Requirements"].

94 B Lab, "B Corporation Community" (last visited May 2019), online: Certified B Corporation <www.bcorporation.net>. In April 2018, B Lab's homepage listed 2,482 B Corporations; in June 2018, it listed 2,100 in fifty countries.

95 B Lab, "Why Pass Benefit Corporation Legislation" (last visited May 2019), online: Benefit Corporation $<$ bcorporation.net/>.

96 B Lab, "Legal Requirements," supra note 93.

97 B Lab, "Certification," supra note 91.

98 Carol Liao, "Limits to Corporate Reform and Alternative Legal Structures" in Beate Sjåfjell \& Benjamin J Richardson, eds, Company Law and Sustainability: Legal Barriers and Opportunities (Cambridge, UK: Cambridge University Press, 2015) 274 at 303. 
has lobbied Argentina, Chile, Colombia, Canada, ${ }^{99}$ Australia, ${ }^{100}$ the United Kingdom, ${ }^{101}$ Italy, ${ }^{102}$ among others, pushing those nation's governments to consider the adoption of the benefit corporation model, despite differing corporate laws and supporting infrastructure for social enterprise in those countries.

Less widely known internationally are other private certifications that have developed in other major industrial countries - for instance, in Europe, the "social enterprise mark" scheme ${ }^{103}$ as well as the concurring "certified social enterprise" badge in the United Kingdom; the two-level ESS/ESUS approval (qualité d'entreprise de l'économie sociale et solidaire and agrément entreprise solidaire d'utilité social) in France; the "It Works!" label (PHINEO Wirkt!-Siegel) in Germany; the Social Enterprise Mark (FSEM) in Finland; and the eS certificate (social economy enterprise) in Poland, to name the most prominent private certifications in the EU. ${ }^{104}$ As well, there is a private social enterprise certification in the works in Australia that has received some attention. ${ }^{105}$ These certifications have not sought a global market through the lobbying of state laws in the same manner as B Lab. Perhaps the most challenging aspect of these private certifications is their role in overseeing these social enterprises while also having them be, in large part, a customer of their services for which they collect fees. ${ }^{106}$ Empirical studies have shown a considerable lack of integrity and oversight in the third-party standard-setting body mechanism that privately regulates American benefit corporations. ${ }^{107}$

\section{CAPITALIZATION OF SOCIAL ENTERPRISES}

Traditionally, donors seeking to support social mandates have turned to non-profit or charitable organizations. ${ }^{108}$ Yet, around the world, the non-profit sector has been suffering from declining or flatlining donations. ${ }^{109}$ Financing continues to be the major challenge facing the non-profit sector. In the past

99 See e.g. Stacey Corriveau et al, "Benefit Corporations in Canada: A Tool to Support Blended Enterprise in Canada" (2011) MaRS Centre for Impact Investing [draft]; Adam Spence, "In search of the Benefit Corporation" (25 November 2010), online: $M a R S<$ www.marsdd.com>.

100 Ellie Coopers "Push for the Benefit Corporation," Pro Bono News (9 March 2016), online: <probonoaustralia.com.au/news>.

101 David Ainsworth "Bring B Corp Model to UK, Government-Backed Review Recommends," Civil Society (6 December 2016), online: <www.civilsociety.co.uk>.

102 "Italian Parliament Approves Benefit Corporation Legal Status" (last visited May 2019), online: Ethical Markets $<$ www.ethicalmarkets.com $>$.

103 Social Enterprise Mark CIC, online: Social Enterprise Mark: Social Enterprise Accreditation Authority <www.socialenterprisemark.org.uk>; Lucy Findlay, "Becoming a Certified Social Enterprise Can Win You Business," The Guardian (16 November 2011), online: <www.theguardian.com>.

104 European Commission, “A Map of Social Enterprises and Their Eco-Systems in Europe - Marks, Labels and Certification Systems” (2014), online: <https://ec.europa.eu/>.

105 Luke Michael "Social Enterprise Certification Launches in Australia," Pro Bono Australia (23 April 2018), online: <probonoaustralia.com.au>.

106 For more on the competing public and private regimes of social enterprise certifications, see F Möslein, "Certifying Good Companies: Regulatory Schemes Driving Corporate Sustainability in a Comparative Perspective” in Sjåfjell \& Bruner, supra note 7.

107 See e.g. Berrey, supra note 9, noting how "the field of U.S. benefit corporations is mostly full of inactivity, activity that is not socially beneficial, and some questionable activity. A considerable number of benefit corporations are subverting and undermining the integrity of the legal innovation"; see also Mohsen, supra note 74, Part III (on statesponsored branding without accountability).

108 Henry B Hansmann, "The Role of Nonprofit Enterprise” (1980) 89:5 Yale LJ 835.

109 John Hailey \& Mark Salway, "New Routes to CSO Sustainability: The Strategic Shift to Social Enterprise and Social Investment" (2016) 26:5 Development in Practice 580. Public giving and philanthropy continues to grow but not at the same pace as the growth in the number of civil society organizations (CSOs) internationally. Public giving only grew by 
three years alone, there has been a decline in monetary donations on almost every continent. ${ }^{110}$ Most NPOs rely heavily on fundraising initiatives, endowments, sponsorships, and volunteer hours from members of the public. ${ }^{111}$ Moreover, since many NPOs by their nature are expected to avoid taking active risks in the marketplace, ${ }^{112}$ many of them rely specifically on government funding. This is particularly true in the areas of health care, social services, and legal advocacy. ${ }^{113}$ As such, NPOs are the first and most immediately affected by government austerity measures. ${ }^{114}$ This financial vulnerability has been a catalyst for many within the non-profit sector to seek alternative means of financing their social mandates and for private sector actors to begin stepping into the role of financiers for many social enterprises. These actors have become known as "impact investors" and have grown exponentially in the last decade. ${ }^{115}$

In order to maximize the mobilization of impact investment capital, several state and non-state actors have formed funds expressly designed to finance social enterprises - and this does not necessarily mean that they are defined as social enterprises via the law. Australia, for example, launched the Social Enterprise Development and Investment Fund in 2010 to "target sustainable support and finance for social enterprises to grow and develop," which is not in reference to any type of legally defined social enterprise. ${ }^{116}$ Other examples include the United Kingdom's Big Society Capital fund, ${ }^{117}$ the Japanese Social Development Fund, ${ }^{118}$ the Portuguese Inovação Social, ${ }^{119}$ and the pending social impact investment fund in South Korea, which is valued at an estimated US \$275.9 million. ${ }^{120}$ Within Europe, the European Social Fund and the European Regional Development Fund have begotten several smaller funds within

$0.8 \%$ in the period 2005-2015, as compared with a growth of $8.5 \%$ in the previous decade. David Bivin et al, "The Philanthropy Outlook: 2015 \& 2016" (February 2015), online: Ignited Fundraising <www.ignitedfundraising.com>. In Australia, public giving to development non-governmental organizations (NGOs) has "flatlined" since 2007. Jonathan Wilson, Jonathan Pryke \& Stephen Howes, "Running Faster to Stand Still: Australian Development NGO Fundraising Costs" (26 November 2015), online: Devpolicy Blog <www.devpolicy.org/>; see also "The Giving Report 2018" (last visited May 2019), online: Canada Helps <www.canadahelps.org/en>.

110 "CAF World Giving Index 2017" (September 2017) at 13, online: Charities Aid Foundation <www.cafonline.org>.

111 See e.g. Companies Act (UK), supra note 64, s 5.

112 Dan Pallotta, Uncharitable: How Restraints on Nonprofits Undermine Their Potential (Medford: Tufts University Press, 2009).

113 Petr Pajas \& Michael Vilain, "Finance of Nonprofit Organizations" in Annette Zimmer \& Eckhard Priller, eds, Future of Civil Society: Making Central European Nonprofit Organizations Work (Weisbaden, Germany: VS Berlag fur Sozialwissenschaften, 2014) 341.

114 David Clifford, "Charitable Organisations, the Great Recession and the Age of Austerity: Longitudinal Evidence for England and Wales" (2016) 46:1 J Social Policy 1.

115 Reported at US \$10.6 billion in new commitments in 2012 and a total of US $\$ 46$ billion in impact investments under management in 2013 in a 2014 survey by JP Morgan and the Global Impact Investment Network of 125 impact investors managing at least US \$10 million each. Clifford Chance et al, "Impact Investing Private Equity Fund Industry: Legal Considerations" (30 April 2015), online: Global Impact Investing Network <www.thegiin.org>.

116 Erin I-Ping Castellas, Jarrod Ormiston \& Suzanne Findlay, "Financing Social Entrepreneurship: The Role of Impact Investment in Shaping Social Enterprise in Australia" (2018) 14:2 Social Enterprise J 130.

117 Big Society Capital, online: <www.bigsocietycapital.com>.

118 Eleanor Warnock, "Japan to Take Dormant Bank Deposits for Charity," Wall Street Journal (2 December 2016), online: $<$ www.wsj.com>; "Japan Social Development Fund" (last modified 2018), online: World Bank Group $<$ www.worldbank.org/en/programs/japan-social-development-fund>; Kanji Tanimoto, "The Emergence of Social Entrepreneurship and Its Strategy in Japan" (2008), online: <www.researchgate.net>.

119 Portugal Inovação Social, online: <inovacaosocial.portugal2020.pt>.

120 "Gov't to Raise 300 Bln Won for Social Impact Investments," Yonhap News Agency (8 February 2018), online: $<$ www.english.yonhapnews.co.kr>. 
different nations that offer a number of debt-financing services to social enterprises. ${ }^{121}$

The classic form of financing for NPOs, in addition to typical member fees, donations, and grants, has been in the form of debt financing. ${ }^{122}$ The key benefits of debt financing are its ready availability and ability to level out fluctuations in revenue cycles. ${ }^{123}$ Currently, state-backed debt instruments constitute the majority of many impact investment portfolios. ${ }^{124}$ This is because these instruments pose the least risk to enterprises that have obtained a certain level of maturity. ${ }^{125}$ Such debt instruments are frequently the direct result of international bodies such as the United Nations and the World Bank. ${ }^{126}$ For example, green bonds are debt-financing instruments in which the proceeds are invested exclusively in projects that generate climate or other environmental benefits. These bonds have grown steadily since 2013, reaching US \$221 billion outstanding issuances in $2017,{ }^{127}$ while social impact bonds are also steadily growing. ${ }^{128}$

The challenge has been that, short of large endowments, most social enterprises operating as NPOs do not have the collateral needed to guarantee a debt, resulting in above-market interest rates. ${ }^{129}$ It is only when organizations mature that debt financing becomes more feasible. As a result, many governments utilize social finance funds to offer loans with favourable interest rates or more flexible loan terms to social enterprises. ${ }^{130}$ In order to preserve the social purpose of the enterprise, some jurisdictions, such as the United Kingdom, legislate interest caps on the loans that the social enterprise undertakes. ${ }^{131}$

Furthermore, the NPO legal structure is generally incompatible to equity financing due to the "public property" role played by such organizations and the incompatibility with equity ownership. ${ }^{132}$ Early impact investors, therefore, would invest in commercial entities with a social mandate. ${ }^{133}$ The mandate often ensured the social impact of their investments through specific terms in their investment agreements or the inclusion of particular social purposes within a company's bylaws and/or articles. Investors may make future rounds of financing or the sale of a company contingent upon the company continuing to fulfill its social mandate. They may also adjust repayment schedules to be based on social impact milestones, such as reductions to the unemployment rate or carbon emissions. Although such clauses have functioned to keep both the investors and directors accountable to an extent, there has been a plethora of arbitration around many of these clauses. ${ }^{134}$ The fact remains that social value is harder to quantify in numeric terms. ${ }^{135}$ Purposes such as community involvement, development of the arts, and the inclusion

121 "Social Enterprises and Their Eco-Systems: A European Mapping Report - Updated Country Report: Italy" (2016) at 31, online: European Commission $<$ https://ec.europa.eu/>.

122 See e.g. Wenli Yan, Dwight Denison \& JS Butler, "Revenue Structure and Nonprofit Borrowing” (2009) 37:1 Public Finance Review 47.

123 Petr Pajas \& Michael Vilain (2004) "Finance of Nonprofit Organizations" in Zimmer \& Priller, supra note $113,341$.

124 Deborah Burand, "Resolving Impact Investment Disputes: When Doing Good Goes Bad” (2015) 48 Wash UJL \& Pol'y 55.

125 Julie Battilana et al, "In Search of the Hybrid Ideal” (2012) 10:3 Stanford Social Innovation Rev 51.

126 World Bank, "Green Bond Impact Report 2018" (2018), online: IBRD Funding Program <treasury.worldbank.org/>.

127 United Nations Development Programme, "Green Bonds" (2018), online: Financing Solutions for Sustainable Development $<$ www.sdfinance.undp.org/>.

128 Andrew Jack, “The Top Global Social Impact Bonds," Financial Times (3 December 2018), online: <www.ft.com>.

129 Dana Brakman Reiser \& Steven Dean, "Creative Financing for Social Enterprise” (2014) 12:3 Stanford Social Innovation Rev at 52.

130 See e.g. Vivek Pandit \& Toshan Tamhane, "Impact Investing: Purpose-Driven Finance Finds Its Place in India" (September 2017), online: <www.mckinsey.com>.

131 CIC Regulations (2009), supra note 64, s. 22.

132 Henry B Hansmann, "The Role of Nonprofit Enterprise” (1980) 89:5 Yale LJ 835.

133 Burand, supra note 124 at 61.

134 Ibid.

135 Geoff Mulgan, "Measuring Social Value” (2010) 8:3 Stanford Social Innovation Rev 38. 
of traditionally marginalized people are important but, nevertheless, harder to track and measure alongside established financial criteria. ${ }^{136}$

In response to the above tension between investors and NPOs, governments have legislated diverse financing laws to balance the competing interests. The creation of social enterprise laws presumably allows businesses to pre-emptively signal and address concerns of how well the business is adhering to its social purpose in order to lessen agency costs. ${ }^{137}$ Commonwealth governments such as Vanuatu purposefully enable their community companies to access outside equity financing, which opens doors for impact investors. ${ }^{138}$ When dealing with any kind of new enterprise, investors are aware that start-up enterprises are much riskier investments, particularly in the first few years of their existence. ${ }^{139}$ Even then, enterprises that do survive the start-up years may take several years to become profitable, thus equity is the preferred method of finance.

Social enterprise laws geared towards the non-profit sector may be viewed as helping to facilitate equity financing and profit sharing for social enterprises. This feature may be the reason why the UK CIC has been relatively popular, with a significant majority of the $17,000+$ CICs to date being companies limited by guarantee (the United Kingdom's equivalent to NPOs), and only a small minority are companies limited by shares. ${ }^{140}$ At the same time, such jurisdictions ensure that the social or community purpose is preserved alongside their profit purposes via other legal features, such as the dividend cap, asset lock, reporting, and regulatory oversight found in the CIC model. ${ }^{141}$ Another is the community contribution company (C3) that was created in the province of British Columbia, Canada, which limits dividends to 40 percent of a C3's annual profit. ${ }^{142}$ Similarly, the legislation restricts the distribution of assets upon wind up via an asset lock. Alternatively, Vanuatu's community company has restrictions on the kind of shareholder that is allowed to hold equity within the company to ensure that the profit remains within the target community. ${ }^{143}$ As noted in Part II, virtually all social enterprise laws, with the exception of the American benefit corporation, feature some form of economic restriction to ensure that the purpose of the social enterprise is maintained, such as requiring a percentage of profits to be reinvested, implementing an asset lock, limiting dissolution rights, placing dividend restrictions or caps, and putting interest limits on loans and/or limitations on property transfers. ${ }^{144}$

136 See e.g. "Measuring Socio-Economic Impact: A Guide for Business" (27 February 2013), online: World Business Council for Sustainable Development $<$ www.wbcsd.org/>.

137 Michael Jensen \& William Meckling, "Theory of the Firm: Managerial Behaviour, Agency Costs, and Ownership Structure" (1976) 3:4 J Financial Economics 305.

138 Companies Act, No 25 (2012) (Vanuatu), s 165 [Companies Act (Vanuatu)].

139 Government of Canada, "Key Small Business Statistics - January 2019” (2019) at 10, online: Key Small Business Statistics <www.ic.gc.ca/sbstatistics>; United States Bureau of Labor Statistics, "Table 7: Survival of Private Sector Establishments by Opening Year" (last visited May 2019), online: Establishment Age and Survival Data $<$ www.bls.gov/bdm/bdmage.htm>.

140 All CICs must operate as either a company limited by shares or a company limited by guarantee in accordance with the Companies Act (UK), supra note 64, s 6; Department for Business, Energy, \& Industry Strategy, Ch. 3 Limited Companies (2016). A CIC limited by shares is similar to a corporation as it raises capital by selling its shares. A CIC limited by guarantee is similar to a non-profit organization (NPO) as it does not have shareholders but members. Once incorporated, a CIC limited by shares cannot convert to a CIC limited by guarantee or vice versa

141 CIC Regulations (2009), supra note 64, s 23.

142 Business Corporations Act, SBC 2002, c 57, s 51.94; Community Contribution Company Regulation, BC Reg 63/2013, s 4(1)(a).

143 Companies Act (Vanuatu), supra note 138, s 165(5).

144 For example, France's menu of legal forms and certifications - including the Société cooperative d'interet collectif (SCIC) (social cooperative), l'ESS (certification), and ESUS (certification) - showcase how a state can build social enterprise laws to meet needs of various constituents. All require a reinvestment of profits into the company; ESUSs 
Equity financing allows social enterprises to compete in some manner with traditional commercial entities not only in regard to offering goods and services to consumers but also as a viable option within an investment portfolio. Typically, investment fund managers traditionally have a fiduciary duty towards their investors, meaning that all of their investment decisions must be made on a commercially prudent basis. ${ }^{145}$ The ability to invest in the organization, hold the board accountable to its commercial as well as social purpose, and distribute a portion of the profits allows investment managers to uphold both their fiduciary duties as prudent investors and as social impact advocates. Additionally, with state-supported impact funds, it seems that governments are facilitating a means for fund managers to both meet their fiduciary duty and support public benefit purposes.

Jurisdictions have also addressed the financing of social enterprises with different approaches, such as allowing for tax incentives (discussed in Part V), employee subsidies, and government social procurement. States that have set low unemployment rates as a key determinant in measuring social enterprise effectiveness often offer employment subsidies, particularly for traditionally marginalized workers. This is most commonly found in WISEs as well as in the Chinese shehui ban and social cooperatives in Europe. Given the proliferation and the ease of quantification, such means of public funding has largely proven successful in both promoting the social mandate of employment inclusion as well as in the economic empowerment of the respective states. ${ }^{146}$ As for government social procurement, some nations have favoured setting a minimum amount of state purchasing that needs to be dedicated to social enterprise, a trend that is growing around the world. ${ }^{147}$ The global snapshot of the diverse approaches to government expenditure reflects the vested interest that many states have in supporting social enterprises and, in particular, the various forms and certifications that businesses have ascribed to via social enterprise laws.

\section{TAXATION OF SOCIAL ENTERPRISES}

A recurrent, critical question in the development of social enterprise laws is how to address taxation. Tax incentives afforded to social enterprises are diverse and intimately connected to the goals of the specific legislation, the circumstances of each country, and the evolving background of taxation on a global level. At least 14 fourteen jurisdictions offer no specific tax benefits to social enterprises. ${ }^{148}$ For those that do, the incentives identified in this article can be broadly characterized as full and partial exemptions from corporate income, sales and value-added tax [VAT] taxation systems, and investor and

have two additional requirements whereby (1) the social purpose must have significant impact on its business (i.e., at least $66 \%$ of business expenses are dedicated to social mission or rate of return on investment is less than 5.96\%) and (2) the average amount paid to five highest paid employees or executives cannot exceed seven times the legal minimum wage, and highest paid employee or executive cannot exceed ten times the legal minimum wage.

145 See e.g. Trustee Act, RSBC 1996, c 464, s 15.2; see also: Trustee Act 2000 (UK), c 29, s 1.

146 "Social Enterprises and Their Eco-Systems: A European Mapping Report - Updated Country Report: France" (2016), online: European Commission <https://ec.europa.eu/>; Directorate General Employment, Social Affairs and Inclusion (July 2016), online: <https://halshs.archives-ouvertes.frt $>$.

147 See e.g. BC Ministry of Social Development and Social Innovation, "Social Impact Purchasing Guidelines" (November 2014), online: Canadian CED Network <https://ccednet-rcdec.ca/en>. Note that in the United Kingdom all public bodies to consider the social value created in contracts. Public Services (Social Value) Act 2012 (UK), c 3; see also Belen Sanchez, "10 Policy Tools that Governments Are Using to Spur Social Enterprise" (14 October 2016), online: World Bank <http://blogs.worldbank.org $>$.

148 These jurisdictions include the United States, Canada, Australia, Sweden, Slovenia, Denmark, and emerging markets Chile, Mexico, Columbia, Bolivia, Solomon Islands, Vanuatu, Vietnam, Malaysia; for Belgium's social finality company, however, there is a possibility to be exempt if economic activity is not for profit, see Table 2. Also note Belgium lowered its general corporate tax rate. See Patrick Boone, "Belgium Decides to Reduce Corporate Tax Rate from $34 \%$ to $25 \%$ " (July 2017), online: $P w C<$ https://news.pwc.be/>. 
employee-centred incentives. Social enterprises also benefit greatly from tax redistribution efforts. ${ }^{149}$ Following a brief overview of these tax incentives, Table 2 highlights the different ways social enterprise laws around the world have addressed taxation.

\section{A. Full Exemptions}

In four countries, five legal structures receive full exemption from corporate tax. Some countries also offer these entities exemptions from sales tax and VAT. ${ }^{150}$ Most countries have paired these exemptions with other tax benefits. The countries that offer full exemptions are quite diverse geographically and culturally - for example, both China, through its shehui ban, and Portugal, through its IPSS, ${ }^{151}$ offer full exemption from corporate tax. A notable characteristic is that these enterprises are similar to traditional NPOs in that they are heavily restricted in distributing profit and they must operate in fields traditionally situated in the non-profit sector for that jurisdiction. Due to these entities' resemblance to traditional NPOs, it may be easier politically for countries to extend tax-exempt status.

\section{B. Partial Exemptions}

In nine countries, 10 legal structures and specific acts offer partial tax exemptions, with one country providing pending legislation. ${ }^{152}$ These exemptions are predominantly based on exempting nondistributable funds and capital (including "locked assets"), ${ }^{153}$ profits reinvested for the social purpose of the enterprise, ${ }^{154}$ and income earned in relation to that purpose. ${ }^{155}$ While most of these tax exemptions fall into these categories, it is worth noting that Greece passed a law in 2016 allowing businesses in select industries and of various legal structures (including social cooperatives) to submit an investment plan that, if approved, would receive government aid, including a tax exemption on income tax or a flat corporate income tax. ${ }^{156}$ Other exemptions also include exemptions from VAT ${ }^{157}$ and governmental "charges."158 To ensure these deductions are used fairly, some countries include anti-avoidance and anti-abuse mechanisms, for example, a total loss of tax benefits for any non-compliance, ${ }^{159}$ a specific rule preventing these enterprises from participating in tax avoidance schemes, ${ }^{160}$ and restrictions on transferring taxexempt assets in the case of dissolution. ${ }^{161}$

Most of the legal structures and certifications offering partial exemptions are social cooperatives or are from countries that had a social cooperative structure in place prior to establishing a general "social

149 In 2013, for example, the Lithuanian government spent $€ 12.75$ million in 2013 as well as state-funded finance. Simonas Gausas et al, "A Map of Social Enterprises and Their Eco-Systems in Europe, Country Report: Lithuania” (2014), online: European Commission $<\mathrm{https}: / / \mathrm{ec}$.europa.eu/>;

150 See e.g. the Chinese shehui ban. Ministry of Finance (Taxation) No 92 (2007).

151 Law 442-B/88 (1988), art 10, online: <www.uma.pt>.

152 France: SCIC; Italy: social cooperative and social enterprise ex-lege; Spain: social initiative cooperative; China: civilianrun educational institute; Thailand: social enterprise; South Korea: social enterprise and social cooperative; South Africa: non-profit company; Greece: social cooperative enterprises; Poland has pending legislation. See e.g. France: SCIC; Italy: social cooperative; Thailand: social enterprise.

154 Italy: social enterprise ex-lege; Thailand: social enterprise.

155 Spain: social initiative cooperative; Lithuania: social enterprise.

156 Investment Incentives Law, Law 4399/2016 (2016), "Statutory Framework for the Establishment of Private Investments Aid Schemes for the Regional and Economic Development of the Country" at 4, online: <www.mfa.gr>.

157 China: civilian-run educational institute.

158 South Korea: social cooperative.

159 Italy: social enterprise ex-lege.

160 South Africa: non-profit company.

161 Ibid. 
enterprise" structure or legal certification, with Thailand as the main exception. The general limiting factor is often revenue-generating activities that diverge too far from the social purpose of the entity or social enterprises in general. This is evident in the statutes that explicitly characterize taxable revenue based on this distinction. For example, the Spanish social initiative cooperative, the Chinese civilian-run educational institute, and the Lithuanian social enterprise's tax liability for revenue explicitly base their connection to the law or organization's social purpose(s). Spain's tax exemptions only apply to income generated by activities "demonstratively related to the purpose" of the enterprise; China provides a list of acceptable sectors to generate tax-free revenue; while Lithuania offers a tax exemption on all income so long as 20 percent or more is not generated from "non-supported" activities. ${ }^{162}$ In Spain, the social cooperatives' tax status is governed explicitly in relation to general cooperatives. ${ }^{163}$ Governments also limit the tax exemption on revenue that may end up in the hands of shareholders, further incentivizing reinvestment into the social purpose of the organization over the accumulation and future distribution of profits. Distributions to shareholders made by the French SCIC, Italian social enterprise ex-lege, and Thai social enterprise, for example, are fully taxed; however, that same surplus is tax free if it is designated as non-distributable, for example, by reinvesting it into asset-locked capital or its social purpose.

\section{Investor Benefits}

In eight countries, 11 legal structures or legislation offer tax incentives to investors. ${ }^{164}$ Investors in social enterprises generally gain personal tax benefits in the form of deductions for indirect ${ }^{165}$ and direct $^{166}$ investment in, and donations to ${ }^{167}$ social enterprises. Indirect investments are investments in intermediary institutions, such as the accredited community development finance institution in the United Kingdom, ${ }^{168}$ which then invest in social enterprises. The tax consequences of these deductions range from partial and full deductibility of the investment, from 5 percent in the United Kingdom to 100 percent in Thailand. Donations are generally treated more favourably than investments. For example, Portuguese individuals (excluding corporations) may assign 0.5 percent of their personal revenue (pre-tax earnings) to an IPSS and deduct these as losses in determining taxable income; in France, those who donate to a SCIC can deduct 66 percent of the amount, up to 60 percent of their taxable income. Entities organized under new legal certifications or structures predominately have access to investor tax benefits. Countries offering these benefits often also institute anti-abuse mechanisms, such as removing all tax benefits from defaulting corporations. ${ }^{169}$

162 Decree No 1501 on the Approval of a List of Non-Supported Activities of the Social Enterprises (29 November 2004). As per the Law on Social Enterprise, No IX-2251 (2004), art 4, which is then defined in Decree No 1501 (2004) on the approval of a list of non-supported activities of the social enterprises. These activities include socially harmful activities (i.e., selling tobacco products, and traditional profit-driven activities), for example, investing and trading in, or developing, real estate.

163 Maria Pilar Alguacil Mari, "Current Problems on the Spanish Taxation of Social Co-operatives: A European Perspective" (2013) at 6, online: Publications $<\mathrm{https} /$ emes.net/publications/>.

164 United Kingdom: CIC; United States: low-profit limited liability company (L3C); France: SCIC and ESUS; Italy: social cooperatives and social enterprise ex-lege; Spain: work-integrated social enterprise (WISE); Portugal: IPSS; Thailand: social enterprise; Philippines (pending).

165 United Kingdom: CIC and the Community Investment Tax Relief; United States: L3C and program-related investment; Italy: social cooperatives and social bonds.

166 France: ESUS; Italy: social enterprise ex-lege; Thailand: social enterprise; Philippines.

167 France: SCIC; Italy: social cooperative; Portugal: IPSS; Thailand: social enterprise; Philippines.

168 "Community Development Finance Institutions and Registration" (8 September 2017), online: Financial Conduct Authority <www.fca.org.uk $>$.

169 United States: L3C. If the L3C's organization is improper, it will cease to exist as an L3C and continue as a traditional limited liability company. Further, the NPO can lose its tax-exempt status; thus, it is a very risky investment. 
Though most investor tax benefits are fairly generic, it is worth noting the Italian social enterprise exlege, which has created a unique tax deduction for investors investing in "early stage" social enterprises, meaning those that have been incorporated for no more than 36 months. Investors are provided with a 30 percent deduction up to a $€ 1$ million; however, the investor must commit to at least a five-year term. Some of the deduction can be accessed after the third year. ${ }^{170}$

\section{Employee-Based Benefits}

Seven countries and eight legal structures and specific acts offer tax exemptions based on whom the organization employs. ${ }^{171}$ Almost all employee-centred tax benefits are connected to WISEs in Europe, with these benefits also attaching to two social cooperatives and one general social enterprise certification, the South Korean social enterprise. South Korea is the only non-European country to offer these benefits. These benefits predominately revolve around exemptions from government payroll taxes, deductions related to the integration of classes of workers, and incentives to encourage the employment of these workers.

Table 2: Taxation of Social Enterprise (Structures and Certifications)

\begin{tabular}{|c|c|}
\hline \multicolumn{2}{|c|}{ Fully exempt from corporate tax } \\
\hline $\begin{array}{l}\text { Lithuania: } \\
\text { Social } \\
\text { enterprise }^{\mathrm{a}}\end{array}$ & $\begin{array}{l}\text { May benefit from income tax exemption if: (1) marginalized and disadvantaged employees } \\
\text { accounts for at least } 40 \% \text {; (2) does not conduct non-supported activities or income received from } \\
\text { such activities } \leq 20 \% \text {; and (3) maintains social enterprise status }\end{array}$ \\
\hline $\begin{array}{l}\text { Portugal: IPSS } \\
\text { and Social } \\
\text { solidarity } \\
\text { cooperative }^{\text {b }}\end{array}$ & $\begin{array}{l}\text { - Generally exempt from corporate tax and VAT as public benefit; taxed on income derived from } \\
\text { non-statutory purposes and dividends from unregistered securities or deposited under legislation; if } \\
\text { incurred }>50 \% \text { revenue from outside activity will lose tax exemption }\end{array}$ \\
\hline $\begin{array}{l}\text { China: shehui } \\
\text { ban }^{\mathrm{c}}\end{array}$ & $\begin{array}{l}\text { Wide-ranging tax exemptions depending on percentage of employed disabled workers: } 50-100 \% \\
\text { exemption from income tax; } 100 \% \text { exemption from business tax, product tax (except for alcohol), } \\
\text { and VAT }\end{array}$ \\
\hline $\begin{array}{l}\text { Philippines } \\
\text { (pending) }^{\mathrm{d}}\end{array}$ & $\begin{array}{l}\text { - Social enterprises with net income of }<10 \text { million pesos are tax exempt; transactions/clients } \\
\text { exempt from documentary stamp tax } \\
\text { incomital assets or shares exempt from capital gains tax; reinvestment for socioeconomic projects } \\
\text { income tax deductible }\end{array}$ \\
\hline \multicolumn{2}{|c|}{ Partial exemptions } \\
\hline France: $\mathrm{SCIC}^{\mathrm{f}}$ & $\begin{array}{l}\text { Generally subject to corporate tax; VAT liability depends on field; non-distributable } \$ \text { or property } \\
\text { tax exempt; losses cannot be carried forward, and deduction does not apply to first year to prevent } \\
\text { corporations with large tax burdens converting to NPO to avoid tax liability }\end{array}$ \\
\hline $\begin{array}{l}\text { Italy: Social } \\
\text { cooperatives }^{\mathrm{g}}\end{array}$ & $\begin{array}{l}\text { - Generally preferable general tax rate and additional tax benefits; non-distributable funds are tax } \\
\text { exempt } \\
\text { 20\% for corporations) }\end{array}$ \\
\hline $\begin{array}{l}\text { Italy: Social } \\
\text { enterprise ex- } \\
\text { lege }^{\mathrm{i}}\end{array}$ & $\begin{array}{l}\text { - Net profits reinvested in business fully deductible } \\
\text { replaced with public commissioner }\end{array}$ \\
\hline
\end{tabular}

170 Legislative Decree no 112/2017, supra note 43.

171 Italy: social cooperatives; Spain: special employment centres and WISE; Lithuania: social enterprise to WISE; Finland: WISE; Greece: KoiSPE; Poland: social cooperative; South Korea: social enterprise. 


\begin{tabular}{|c|c|}
\hline $\begin{array}{l}\text { Spain: Social } \\
\text { initiative } \\
\text { cooperative }\end{array}$ & $\begin{array}{l}\text { Profit from activity demonstratively related to purpose tax exempt, otherwise revenue taxed at } \\
10 \% \\
\text { professional, or artistic activity) }\end{array}$ \\
\hline $\begin{array}{l}\text { China: Civilian- } \\
\text { run educational } \\
\text { institute }\end{array}$ & $\begin{array}{l}\text { Exempt from selected taxes: VAT for revenue from educational labour, technology development, } \\
\text { consultation and kindergarten services; enterprise income tax for technology development, services } \\
\text { by higher education institutions and occupational schools, and government funds or allowance }\end{array}$ \\
\hline $\begin{array}{l}\text { Thailand: } \\
\text { Social } \\
\text { enterprise }^{k}\end{array}$ & $\begin{array}{l}\text { Non-distributable revenue and assets tax exempt; corporation income tax exempt if reinvests } \\
100 \% \text { of profits or benefits certain groups } \\
\text { - Can issue } \leq 30 \% \text { of profits in dividends, share of profits, or capital reduction on fully taxed basis }\end{array}$ \\
\hline $\begin{array}{l}\text { South Korea: } \\
\text { Social } \\
\text { enterprise }^{1}\end{array}$ & - Legislation authorizes wide range of tax incentives and reductions under discretion of state \\
\hline $\begin{array}{l}\text { South Korea: } \\
\text { Social } \\
\text { cooperative }^{\mathrm{m}}\end{array}$ & $\begin{array}{l}\text { - Business and property exempt from charges except taxes imposed by central and local } \\
\text { governments } \\
\text { - Can be certified as social enterprise }\end{array}$ \\
\hline $\begin{array}{l}\text { South Africa: } \\
\text { Non-profit } \\
\text { company }^{n}\end{array}$ & $\begin{array}{l}\text { Fully exempt if maintains non-profit status; can maintain while carrying on any business, trade, } \\
\text { or undertaking consistent with, or ancillary to, stated objectives; only reasonable efforts must be used } \\
\text { to ensure it is applied to objective; includes anti-avoidance rule }\end{array}$ \\
\hline $\begin{array}{l}\text { Greece: Social } \\
\text { cooperative } \\
\text { enterprises }^{\mathrm{O}}\end{array}$ & $\begin{array}{l}\text { - In select industries, can receive government aid, including tax exemption from income tax that } \\
\text { results from current tax legislation; on profits realized before taxes from all corporation activities; or } \\
\text { flat tax corporate income tax }\end{array}$ \\
\hline $\begin{array}{l}\text { Greece: } \\
\text { KoiSPE }\end{array}$ & $\begin{array}{l}\text { - Contributed pubic property money exempt from corporation income tax and municipal taxes, } \\
\text { excluding VAT }\end{array}$ \\
\hline \multicolumn{2}{|l|}{ Investor benefits } \\
\hline $\begin{array}{l}\text { United } \\
\text { Kingdom: } \mathrm{CIC}^{\mathrm{q}}\end{array}$ & $\begin{array}{l}\text { nunity investment tax relief, those who invest in community development finance } \\
\text { s), which then may lend or invest in qualifying CICs, can access tax relief of } 5\end{array}$ \\
\hline $\begin{array}{l}\text { United } \\
\text { L3C }\end{array}$ & $\begin{array}{l}\text { "Flow through" entity - small profit and losses flowed through to NPOs and tax-exempt status } \\
\text { maintained }\end{array}$ \\
\hline France: SCIC & $\begin{array}{l}\text { Tax credit } \leq 66 \% \text { of donated amount; non-corporation donations to associations of public interest, } \\
\text { foundations, and endowment funds tax deductible to } \leq 60 \% \text { of taxable income }\end{array}$ \\
\hline France: ESUS ${ }^{t}$ & $\begin{array}{l}\text { - } 25 \% \text { deduction in small and medium enterprises (SME) investments } \leq € 50,000 \text { for single } \\
\text { investor; can reduce solidarity tax by } 50 \% \text { of SME investment } \leq € 45,000 \text { for direct and } € 18,000 \text { for } \\
\text { fonds communs de placement dans l'innovation (venture capitalist trust for innovation) or via fonds } \\
\text { d'investissement de proximité (local investment fund) }\end{array}$ \\
\hline $\begin{array}{l}\text { Italy: } \\
\text { coop }\end{array}$ & $\begin{array}{l}\text { Tax exemptions for private donations; tax benefits for those who buy solidarity bonds, issued to } \\
\text { finance non-profit activities }\end{array}$ \\
\hline 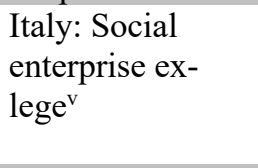 & $\begin{array}{l}\text { - Investors in early stage (incorporated no more than } 36 \text { months) eligible for income tax deduction } \\
\text { of } 30 \% \text { of investment } \\
\text { - Can deduct } \leq € 1 \text { million; however, investor must commit to at least five-year term but can access } \\
\text { some deduction after the third year }\end{array}$ \\
\hline Portugal: IPSS ${ }^{w}$ & $\begin{array}{l}\text { Non-corporation investors may assign } 0.5 \% \text { of personal revenue to IPSS and considered costs or } \\
\text { losses for determining taxable income }\end{array}$ \\
\hline $\begin{array}{l}\text { Thailand: } \\
\text { Social } \\
\text { enterprise }^{\mathrm{x}}\end{array}$ & $\begin{array}{l}\text { - Corporation income tax exemption of } 100 \% \text { of amount invested if social enterprise properly } \\
\text { constituted up to } 2 \% \text { of net profits }\end{array}$ \\
\hline $\begin{array}{l}\text { Philippines } \\
\text { (pending) }\end{array}$ & $\begin{array}{l}\text { - Investor contributions (money or property) as equity investment of donations; full deduction from } \\
\text { gross income and generally deductible }\end{array}$ \\
\hline \multicolumn{2}{|l|}{ Employee be } \\
\hline $\begin{array}{l}\text { aly: Social } \\
\text { ooperative }^{z}\end{array}$ & $\begin{array}{l}\text { - Disadvantaged members of labour market exempt from payment of national insurance } \\
\text { contributions }\end{array}$ \\
\hline
\end{tabular}




\begin{tabular}{|c|c|}
\hline $\begin{array}{l}\text { Spain: Special } \\
\text { employment } \\
\text { centre }^{\text {aa }}\end{array}$ & - Tax benefits linked to hiring of disabled workers; further reductions related to profit status \\
\hline Spain: WISE ${ }^{\mathrm{bb}}$ & $\begin{array}{l}\text { - Reductions in social security contributions for at-risk workers; subsidies for equipment and } \\
\text { wages; fully tax exempt if not for profit } \\
\text { - Regional subsidies vary but based on hiring integration workers, technical support workers, and } \\
\text { investments }\end{array}$ \\
\hline $\begin{array}{l}\text { Lithuania: } \\
\text { Social } \\
\text { enterprise } \\
\text { certification to } \\
\text { WISE }^{\text {cc }}\end{array}$ & $\begin{array}{l}\text { - Tax benefits differ based on whether employing persons with disabilities. If so, grants for } \\
\text { adaptation of work environment for disabled employees, administrative and transportation costs. If } \\
\text { not, wage subsidies, state social insurance exemptions, and less substantial grants }\end{array}$ \\
\hline $\begin{array}{l}\text { Finland: } \\
\text { WISE }^{\text {dd }}\end{array}$ & $\begin{array}{l}\text { - Support systems or tax reliefs only for WISEs and those who operate on not-for-profit basis; a } \\
\text { WISE that employs under-integrated work populations can access wage subsidies, employment } \\
\text { policy assistance, and increased government investments }\end{array}$ \\
\hline $\begin{array}{l}\text { Greece: } \\
\text { KoiSPE }^{\text {ee }}\end{array}$ & $\begin{array}{l}\text { Specific tax-free benefits to employees and members - for example, members that are mental } \\
\text { health patients and thus receive sickness benefits can maintain their benefit eligibility while being } \\
\text { members and employees }\end{array}$ \\
\hline $\begin{array}{l}\text { Poland: Social } \\
\text { cooperative }^{\text {ff }}\end{array}$ & - Exempt from social security contributions during the first two years of existence \\
\hline $\begin{array}{l}\text { Korea: Social } \\
\text { enterprise }\end{array}$ & $\begin{array}{l}\text { - May receive employment-related subsidies including on insurance premiums and pension } \\
\text { contributions }\end{array}$ \\
\hline
\end{tabular}

Notes:

${ }^{a}$ Republic of Lithuania Law on Corporate Income Tax, No IX-675 (20 December 2001).

b Law 442 B/88, online: <www3.uma.pt>; Cooperative Code, Law 51/96 and Legislative Decree 7/9; Ministry of Finance and Public Administration, "The Portuguese Tax System" (2009), online: <www.mfa.gov.ir>.

c Measures for Welfare Enterprise Accreditation of Qualification (2007); Shanghai University of Finance et al, "China Social Enterprise and Impact Investment Report" (2013) at 15, online: <https://uhnw-greatwealth.ubs.com>.

d The Poverty Reduction through Social Entrepreneurship Act (pending), online: <www.isea-group.net>.

e This is an excise tax imposed on certain documents executed, delivered, or recorded.

${ }^{f}$ Law No 2007-1824 (2007), art 50; Law No 47-1775 (1947), art 11; Les SCIC, "Tax System” (2016), online: $<$ www.les-scic.coop>.

g Law 381/91 (1991), art 10, DL 633/72 (for VAT); see also Paul Gosling, "Social Co-operatives in Italy: Lessons for the UK" (2011) at 10, online: <http://socialeconomyaz.org/>.

h This is a 3\% tax payable by all cooperatives for mutual self-financing aimed at financing new cooperatives.

${ }^{\mathrm{i}}$ Law No 155/2006 and Decree of 17 July 2018 by the Italian Council of Ministers.

j National Law 20/1990 and 49/2002; Maria Pilar Alguacil Mari, "Current Problems on the Spanish Taxation of Social Co-operatives: A European Perspective" (2013) at 5, online: Publications < https:/emes.net/publications/>.

k Social Enterprise Promotion Act, Decree on Tax Exemption (621)2559 (2016); Tilleke \& Gibbins, "A Legal Framework to Promote Social Enterprises in Thailand," Bangkok Post (17 March 2017), online: $<$ www.bangkokpost.com>.

${ }^{1}$ Social Enterprise Promotion Act (South Korea), online: <www.moleg.go.kr $>$.

${ }^{m}$ Framework Act on Cooperatives, online: <www.ilo.org $>$.

${ }^{n}$ Companies Act (S Afr), 2008, No 71 (2008); Income Tax Act (S Afr), No 58 (1962), s 30; Legal Counsel, “Tax Exemption Guide for Public Benefit Organisations in South Africa" (2018), online: South African Revenue Services $<$ www.sars.gov.za>.

${ }^{\circ}$ Law 4399/2016; Hellenic Republic Ministry of Economy, Development and Tourism, "Statutory Framework for the Establishment of Private Investments Aid Schemes for the Regional and Economic Development of the Country" (2016), online: <www.mfa.gr>; see also <www.social-economy.com>.

p No 12 Presidential Decree 60/2007, art 27, online: <https://eur-lex.europa.eu>.

q Income Tax Act 2007 (UK), s 333-82.

${ }^{\mathrm{r}}$ Code of Federal Regulations 53.4944-3, online: $<$ https://lawecommons.luc.edu $>$.

s Taxes Nos BOI-IR-RICI-250 (generally) and 250-20. 
${ }^{\mathrm{t}}$ Law No 2014-856 (2014), art 11; Tax Code, art 199; Portal of Economy, Finance, Action, and Public Accounts (2018), online: <www.economie.gouv.fr>.

u Law 381/91, online: <http://socialeconomyaz.org $>$.

${ }^{v}$ Legislative Decree No 112/2017, online: <https://thephilanthropist.ca $>$.

${ }^{w}$ Law 442 B/88, online: <www3.uma.pt $>$.

${ }^{x}$ Decree on Tax Exemption (621) BE 2559 (2016); online: <www.bangkokpost.com>.

y Poverty Reduction through Social Entrepreneurship Act (pending); online: <www.isea-group.net>.

${ }^{z}$ Law 381/91; see also Gosling, "Social Co-operatives in Italy" at 10.

aa Social Integration for Disabled People Act, Law 13/1982 (1982); for an overview of these deductions, see the advocacy group EuroBlind, "Spain - Article 27" (last visited June 2019), online: EBU $<$ www.euroblind.org/convention/article-27/spain\#10>; as extended by the Non-Discrimination Act, Law 51/2003 (2003) and the Equal Opportunities Act, Law 49/2007 (2007).

bb Law 44/2007 (2007); Law 44/4/2013 (2013), online: <https://emes.net>.

cc Simonas Gausas et al, "A Map of Social Enterprises and Their Eco-Systems in Europe, Country Report: Lithuania" (2014) at 8, online: European Commission <https://ec.europa.eu/>; Law on Social Enterprises, Law 1/6/2004 (2004, amended in 2011); Employment Support Law (2006), art 26.

dd Finnish Act on Social Enterprises, No 1351/2003 (2003); see also Silja Russel et al, “A Map of Social Enterprises and Their Eco-Systems in Europe, Country Report: Finland" (27 June 2014), online: European Commission $<$ https://ec.europa.eu/>.

ee Hellenic Republic Ministry of Economy, Development and Tourism and Enterprise Greece Invest and Trade, Investment Incentives Law, Law 4399/2016 (2016), labelled "Statutory Framework for the Establishment of Private Investments Aid Schemes for the Regional and Economic Development of the Country" (2016) at 4, online: $<$ www.mfa.gr $>$.

${ }^{\mathrm{ff}}$ Act on Social Employment (2003); along with the Law on Social Cooperatives (2006).

gg Social Enterprise Promotion Act (2007) (Korea), art 13(2); online: <www.icnl.org

\section{E. Social Enterprise Taxation Landscape}

The taxation of corporate entities is continuously developing, affected by both domestic and international trends, thus offering a complicated landscape for social enterprises to navigate. Corporations are generally provided with favourable tax incentives; however, the complexity that surrounds them prevents wider access. Cross-border capital flows lead to some countries modifying their tax systems to attract capital. At the very least, state abilities to domestically determine their own tax policy is constrained by global markets. ${ }^{172}$ International tax competition, defined in one study as "the uncooperative setting of source-based taxes on corporate income where the country is constrained by the tax setting behaviour of other countries," $" 173$ has already played a role in reducing corporate tax rates compared to personal income tax rates. ${ }^{174}$ In Canada, for example, the combined federal and provincial corporate tax rates range from 26.5 per cent to 30 percent. ${ }^{175}$ Though unique to Canada, a social enterprise could qualify as a Canadian controlled private corporation thereby only having a net marginal rate of 10-14.5 percent on the first

172 For the European Union, see Veronika Sobotkova, "Revisiting the Debate on Harmful Tax Competition in the European Union” (2012) at 343, online: ACTA <acta.mendelu.cz/>; for Canada, see Brian J Arnold, “Canada's International Tax System Historical Review, Problems and Outlook for the Future” (16 February 2018) at 4, online: Centre for International Governance Innovation <www.cigionline.org $>$.

173 Michael P Devereux \& Simon Loretz, “What Do We Know About Corporate Tax Competition?” (2013) 66:3 National Tax J 745 at 746.

174 For a general overview of corporate tax in different countries, see "Worldwide Tax Summaries Online" (2018), online: $P w C<$ www.taxsummaries.pwc.com $>$.

175 For general worldwide corporate tax rates, see "Corporate Income Tax" (2018), online: OECD iLibrary<www.oecdilibrary.org $>$. 
$\$ 500,000$ of active business income. ${ }^{176}$ This is drastic when compared to the fact that the highest net marginal rates for personal income tax in Canada, for example, range from 43.5 percent to 54 percent.

At the same time, administrating taxation is already costly and inefficient due to its complexity and countries' inability to proactively monitor tax compliance. Despite countries such as the United Kingdom setting up government offices to address tax simplification, ${ }^{177}$ these codes are becoming exponentially more complex. In the United States, for example, one group estimated that, as of 2013, the entire doctrine of tax law increased from its original four pages to now over 70,000. ${ }^{178}$ Given the sheer volume of income tax law, it is unsurprising that the median cost of the collection ratio (meaning for every tax dollar earned the government spends \$X) equalled 0.735 in 2011, according to the most recent survey for all countries that are members of the Organisation for Economic and Co-operation Development. ${ }^{179}$ Proactively, administrating boutique tax exemptions, such as these social enterprise incentives, is particularly difficult due to the need to train experts and incorporate these entities into a regulatory regime. The antiavoidance/abuse rules posited in the statutes may provide a deterrent effect; however, they are ex-post solutions and do not lower costs.

Social enterprises and their corresponding laws exist alongside traditional corporations and an array of other legal forms, creating a complicated taxation system. These organizations sit awkwardly and varyingly in between traditional corporations and NPOs in terms of how much they pursue social value and how much they restrict profit. Scholars have noted that social enterprises interrupt the traditional hybrid taxation system based on for-profit traditional corporation subject to tax and the social purpose organization, cooperatives, or charities, for example. ${ }^{180}$ Yet these scholars argue that the taxation measure for social enterprise increases its complexity by seeking to maintain this traditional hybridity - for example, by exempting expenditures made to pursue the organization's social purpose. ${ }^{181}$ Social enterprise taxation measures, whether successful or not, should reflect the entrepreneur's choice, and their compromises inherent in competing corporate forms, if a tax is to be efficient. In Canada, for example, the $\mathrm{BC}$ legislature explicitly proposed the benefit company as a complementary form to the more profitrestricted community contribution company. To encourage those who wish to make more profit to use the benefit company and those who wish to pursue social value more aggressively, the BC legislature stated that it does not intend to provide any tax benefit to the benefit company. ${ }^{182}$

The role that specific social enterprises and corresponding laws fulfill and the international taxation context, thus, highlight the inadequacy of current taxation measures. Social enterprise law, at its core, seeks to encourage diverse and socially conscious entrepreneurs to take action through commerce and eliminate barriers preventing them from doing so. Current tax benefits for social enterprises may not only

176 Active business income means income from an active business which is carried on by it, including any income for the year pertaining to or incident to that business, other than income for the year from a source in Canada that is a property (see section 125(7) of the ITA).

177 UK Office of Tax Simplification, an independent office of the HM Treasury, online: <www.gov.uk>.

178 Andrew Lundeen, “The Income Tax Code Spans More Than 70,000 Pages” (23 October 2013), online: Tax Foundation <www.taxfoundation.org>. In Canada from 1971 to 2014, the entire doctrine of Income Tax Act increased from 574 standardized pages to 2,612. See Francois Vaillancourt et al, "Measuring Personal Income Tax Complexity in Canada" (April 2016), online: Fraser Institute <www.fraserinstitute.org>.

179 “Government at a Glance 2013” (2013), online: OECD iLibrary <www.read.oecd-ilibrary.org>.

180 Sheila Killian \& Philip O'Regan, "Taxation and Social Enterprise: Constraint or Incentive for the Common Good” (3 Nov 2018) 10:1 Journal of Social Entrepreneurship 1 (note this article was published on Taylor and Francis online after this article was accepted for publication).

181 Ibid.

182 British Columbia, Legislative Assembly, Hansard, 41st Parl, 3rd Sess, No 136 (14 May 2018). 
be economically inefficient from a tax perspective, but they may also be inequitable, preventing this core goal of social enterprise overall. The current state of taxation is already favourable towards corporations. Although sophisticated entities have the knowledge and resources to navigate and enjoy the full extent of any tax benefits offered, this is not true for all social enterprises. Though tax measures for sophisticated or financially successful corporations are not bad in and of themselves, they should be paired, as some individuals have noted, with measures that "also support indigenous entrepreneurship and hybrid organizations." 183

If governments are seeking to encourage a variety of social enterprises and wider access to capital, a greater focus could be placed on simplifying taxation for these entities and on incentives that shift the administrative burden off the social enterprises. The Zentrum für Europäische Wirtschaftsforschung (Leibniz Centre for European Economic Research) argues that "disproportionate tax compliance costs for small entities constitute the most compelling argument for a special tax treatment." 184 These could include taxation measures such as indirect investor-centred exemptions or other non-tax financing initiatives, as suggested within the academic literature. ${ }^{185}$

Countries with indirect investor-centred exemptions, such as the United Kingdom's community investment tax relief ${ }^{186}$ and Italian solidarity bonds initiatives, ${ }^{187}$ provide concrete examples of tax initiatives that provide more equitable access to finance. Under these measures, intermediaries distribute these resources, allowing targeted access to resources, removing, to an extent, investor's choices in enterprise, while these organizations and the investor assume more of the administrative burden. In fact, in a policy brief, the United Nations showed support for providing tax benefits to those whom directly or indirectly invest in small- and medium-size enterprises. The United Nations stated that the Asian-Pacific markets could see a greater impact from investing, but "appropriate tax relief will be required to attract large scale investments in corporations which create public value but may generate below-market returns." 188 The inherent difficulty in isolating the impact of certain tax benefits and the lack of research engaging in this type of analysis regarding social enterprises leaves some pause in declaring which are relatively successful taxation measures.

\section{CONCLUSION}

The importance of recognizing the global emergence of social enterprise lawmaking around the world has heightened of late. Increasingly, legislators around the world are being approached by a range of interested parties to pursue laws aimed at harnessing businesses towards social good. As noted within this article, benefit corporation legislation, in particular, is being lobbied for in a number of countries, ${ }^{189}$ yet legislators should avoid "norm creation" by private interest groups ${ }^{190}$ and be cognizant of the plethora of

183 Killian \& O'Regan, supra note 180.

184 Sören M Bergner et al, "The Use of SME Tax Incentives in the European Union” (15 January 2017), online: SSRN $<$ papers.ssrn.com>.

185 Killian \& O’Regan, supra note 180.

186 UK Community Investment Tax Relief, online: Gov.UK<www.gov.uk>.

187 Paul Carrel, “Bundesbank Official Says Italy Could Issue Solidarity Bonds,” Reuters (27 October 2018), online: $<$ www.reuters.com>.

188 United Nations, "Policy Approaches to Scale Impact Investment in Asia-Pacific" (April 2017), online: Economic and Social Commission for Asian and the Pacific <www.unescap.org/>.

189 See B Lab, "International Legislation," supra note 4.

190 Andrew MacLeod, "Taking Care of Business? Experts Call New BC Law a Gift to Corporations," The Tyee (4 June 2019), online: <https://thetyee.ca/News/2019/06/04/Experts-Call-New-BC-Law-Gift-To-Corporations/>, quoting Joel 
options available to generate social benefits from the private sector. This article canvasses the wide range of state-led social enterprise law initiatives around the world to stimulate more fulsome discussions within political groups. We hope to invigorate debates by unearthing the international array of innovative legal methods seeking to regulate social purpose, cultivate greater access to capital, and produce efficient tax regimes for social enterprise and social enterprise-type businesses.

At this embryonic stage of its development, we remain agnostic on the benefits of social enterprise laws to date. ${ }^{191}$ The 2015 United Nations Sustainable Development Goals (SDGs) ${ }^{192}$ have posed a challenge for nations, and whether social enterprise laws aid in achieving these goals within existing legal ecosystems remains an open question. As Table 1 highlighted, thus far it seems most social enterprise laws operate only to serve niche sectors of the market, which may very well be an effective and justifiable purpose for their existence. For example, European WISEs and other social enterprise laws designed to reach particular communities address important social needs beyond simply numbers, including the employment of members of marginalized groups. Social enterprises laws could be integral in growing a nation's social economy if legislators are strategic in their deployment.

However, some laws designed to carve separate legal vehicles for "good" businesses have been met with much criticism, including, in particular, their lack of accountability and transparency and negative impact on the voluntary sector. ${ }^{193}$ New legal structures that may be coined as social enterprise laws in some jurisdictions would not even qualify under basic informal definitions of "social enterprise" in others. ${ }^{194}$ The road to meaningful reform is rife with risks, such as regulatory capture, social washing, inefficient and inequitable tax treatments, and illegitimacy due to a lack of regulatory oversight. When implemented poorly, social enterprise laws risk becoming watered down tools that only bolster the status quo of regular businesses. Lawmakers must consider whether social enterprise laws are capable of providing meaningful legal features that ensure dual economic and social mandates are able to coexist and thrive, while also meeting the particular needs of entrepreneurs to make the model attractive. The incentives must be there as well accountability and legal remedies in the case of default.

The seemingly innocuous global social enterprise lawmaking phenomenon appears to be spreading across continents, with no indications of slowing down. With Asia's ascendance in the new global order, ${ }^{195}$ Anglo-American lawmakers should contemplate the legal developments occurring in jurisdictions that are often overlooked in the literature, taking advantage of available data to consider the effects these laws have had within those jurisdictions. One should not discount the potential impact social enterprise laws could bring to strengthening society's social fabric or to further advancing nations towards the SDGs if

Bakan's letter to BC politicians: "By delegating detailed norm creation and enforcement to private typically for-profit certifiers, [the benefit company legislation] propels the privatization trend."

191 For a discussion on whether social enterprise laws serve to promote greater corporate sustainability overall, see Carol Liao, "Social Enterprise Law: Friend or Foe to Corporate Sustainability?” in Sjåfjell \& Bruner, supra note 7

(forthcoming 2019).

192 United Nations Sustainable Development Goals (2015), online: <https://sustainabledevelopment.un.org>.

193 Alicia Plerhoples, "Nonprofit Displacement and the Pursuit of Charity through Public Benefit Corporations" (2017) 21 Lewis \& Clark L Rev 525; Mohsen, supra note 74; Doug Batey, "ABA Business Law Section Actively Opposes LowProfit LLCs," Lexology (3 July 2012), online: <https://lexology.com>.

194 See supra note 3.

195 Furthermore, the ascendance of Asia on the global stage and China's place as a global superpower may soon require there to be a reconception of our notions on how to achieve a sustainable world. See United Nations, "Global trends and challenges to sustainable development post-2015" (2013) World Economic and Social Survey, online: <http://un.org>; R. Edward Grumbine, "China's Emergence and the Prospects of Global Sustainability" (2007) 57:3 BioScience 249. 
utilized and implemented correctly. ${ }^{196}$ But, with changing risk appetites under our climate emergency, ${ }^{197}$ laws appear on the rise to compel all businesses to act as responsible corporate citizens, whether businesses like it or not. ${ }^{198}$ Initiatives to carve separate legal vehicles for voluntary "good" businesses cannot be used as a distraction to avoid widespread corporate accountability, where new legal structures and certifications requiring businesses "to operate in a responsible and sustainable manner"199 are put forward as a modicum of choice for organizations (and some with even less accountability than existing options). ${ }^{200}$

Social enterprise laws may add little to reform efforts, only serving as a stopgap or, worse, a distraction to transformative governance and regulatory reform of traditional corporations. They must also not detract from, or replace efforts at, expansive social welfare reform. ${ }^{201}$ Social enterprise laws may need to remain focused on targeting sectors and communities in greatest need, while ensuring such laws do not usurp broader corporate reform efforts. Advocates of social enterprise laws will need to work hard to show their value in their own jurisdictions while navigating responsibly within evolving legal and regulatory frameworks. The challenge for legislators, should they choose to develop alternative legal structures or certifications for social enterprise, will be in creating effective and meaningful options that do not harm broader reform efforts but are legitimate, accountable, and work in favour of societal flourishing rather than against it.

196 For a discussion on some of the errors experienced in the implementation on social enterprise laws, see Liao, "Early Lessons," supra note 17.

197 David A Lubin \& Daniel C Esty, “The Sustainability Imperative” (2010) 88:5 Harvard Business Rev 42.

198 E.g., in Canada, see Clarke Hunter, QC, "The Long Reach of Canadian Civil Liability for Human Rights Impacts of Foreign Operations" (March 2017), online: <www.nortonrosefulbright.com>; Choc v HudBay Minerals Inc, 2013 ONSC 1414, 17 BLR (5th) 303; Garcia v Tahoe Resources Inc, 2017 BCCA 29, 92 BCLR (5th) 249; Araya v Nevsun Resources Inc, 2017 BCCA 401 (with a decision awaiting from the Supreme Court of Canada); see also Killoran et al, "Climate Change Litigation Arrives in Canada," Osler (5 February 2019), online: <http://osler.com>; Umair Irfan, "Pay Attention to the Wave of Climate Change Lawsuits," The Vox (4 June 2019), online: <http://vox.com>.

199 BC benefit company legislation, Bill M209, s 51.993.

200 MacLeod, supra note 190; Mohsen, supra note 74, Part III; R André, “Assessing the Accountability of the Benefit Corporation: Will This New Gray Sector Organization Enhance Corporate Social Responsibility?” (2012) 110 J Business Ethics 133 (concluding with "significant design-based concerns about the utility of the benefit corporation as an effective organization for implementing CSR [corporate social responsibility]").

201 Plerhoples, supra note 193. 